\title{
الأثر الفقهي ا في الخطاب النحوي
}

أ.م. د . علي فرحان جواد

جامعة المثنى - كلية التربية

d.ali_i@yahoo.com

الكلمات المفتاحية: الأثر الفقهي، الخطاب النحوي.

الملخص

وقف البحث عند ظاهرة في الخطاب النحوي العربي مثلت مرجعية في التأسيس والتحليل والتوجيه، وهي الأثر الفقي الذي كان حاضراً في ثلاثة محاور : النص، والاجتهاد، والأحكام، ليحاول الباحث سبر أغوار الخطاب مهتدياً بأقوال العلماء في تثخيص نقاط اللقاء والافتراق بين الخطابين ، وآليات النقل التي تحولت من الفقه إلى النحو، في مراحل ثلاث: مرحلة التأسيس في المدونة النحوية عند سيبويه، وفي مرحلة التأصيل في

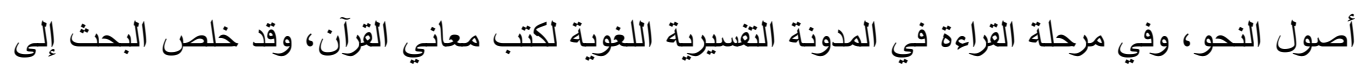
جملة نتائج، منها:

إن الخطاب النحوي تأثر معرفياً بالخطاب الفقهي بشقيه: الأصول بأدلته الشرعية، والفقه بأحكامه الاستنباطية في مجالات متعددة: منهجاً، ومصطلحاً مع فارق تحويلي تتسجم مع طبيعة العلم، فلم يكن نسخاً تقريرياً، لينحو بهما منحى مغايراً. وقف البحث على أبعاد الدرس اللغوي بنيوياً في الصوت والصرف والتركيب؛ لأنه انتحاء لسمت العرب في كلامهم، وحدد البحث ذلك الأثر الاصطلاحي والمنهجي باتجاهات ثلاثة في الخطاب النحوي: الاتجاه الأول الاتجاه القاعدي المتمثل في القاعدة النحوية ، والاتجاه الثاني، اتجاه التأصيل التتظيري الاستباطي المتمثل بكتب أصول النحو العربي ، والاتجاه الثالث في الخطاب النحوي الاتجاه الاستعمالي القائم على قراءة النصوص على وفق الاتجاهيين السالفين. 
Juristic effect in grammar speech

Assist.Prof. Dr.Ali Farhan Jawad

AL-Muthanna University- Education College

Arabic Department/linguistics

The search has focused on phenomenon in the Arabic grammar speech which represents reference in the establishment ,analysis and guidance, it is juristic effect which it was presented in three axes :Text, studiousness and determination in order to the researcher tries to explore dents of speech guided by speeches of scientists in personification of meeting and separation points between two discourses and mechanisms of transport that have been transformed from jurisprudence into grammar in three stages: stage of establishment in the grammatical legislation at Sibweh, stage of rooting in origins of grammar and stage of reading in linguistic explanatory legislation for books of Quran meanings. The research has concluded with series of results are :

-Grammatical speech is affected ideally with juristic speech with two branches: origins with its legal evidences and jurisprudence with its elicitational rules in several fields: method and term with conversional difference consistent with nature of science, it was not a reported copy to follow them into different way

-The search focused on dimensions of linguistic lesson structurally in phonetics ,grammar and structure because it behavior for attribute of Arabs in their speech ,the search has determined this conventional and systematic impact with three directions in grammatical speech :first direction is a basic one which represented in grammatical basis, second direction is direction of indicative and deductive rooting which represented with books of origin of Arabic grammar and third one is used direction which based on reading of texts according to two previous directions0 


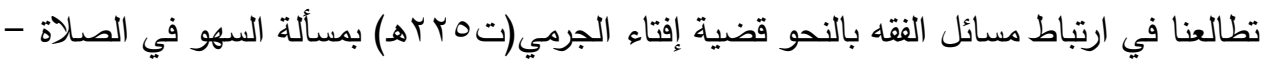

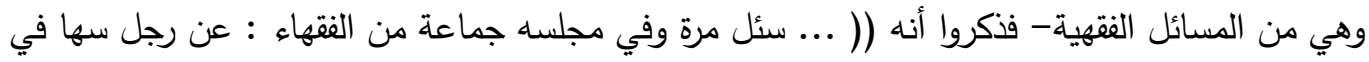

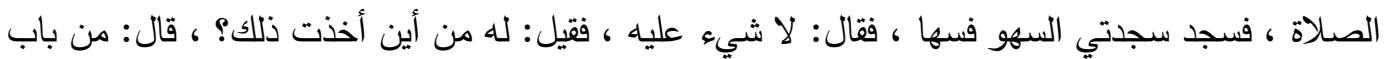

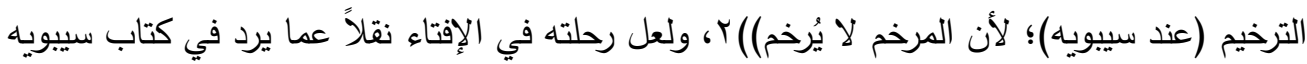

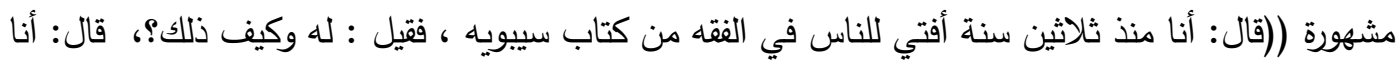

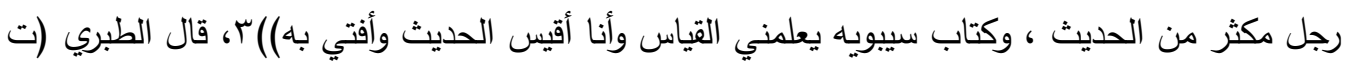

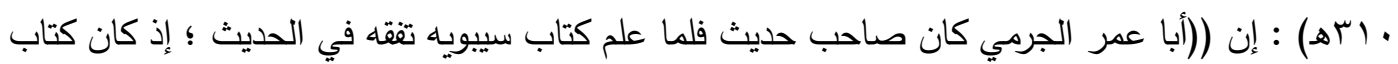

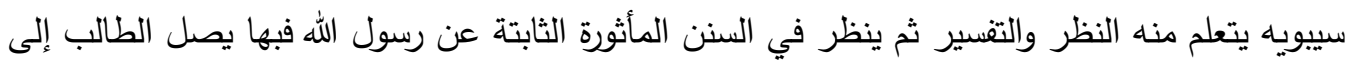

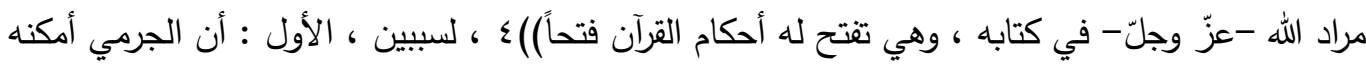

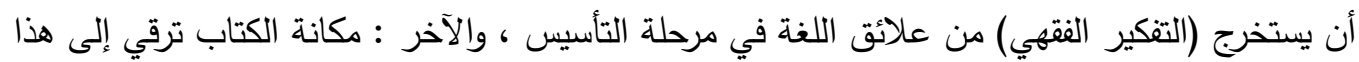

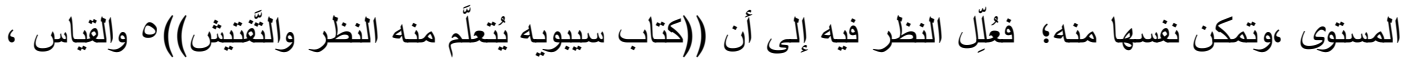

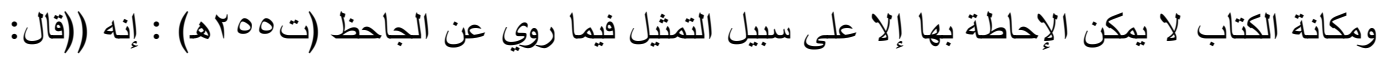

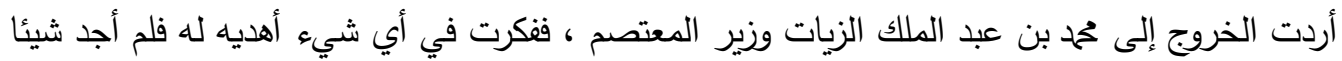

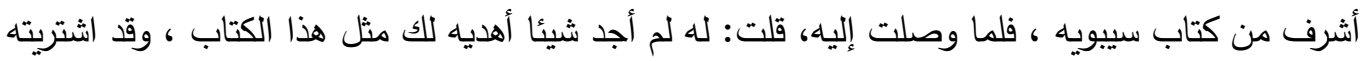

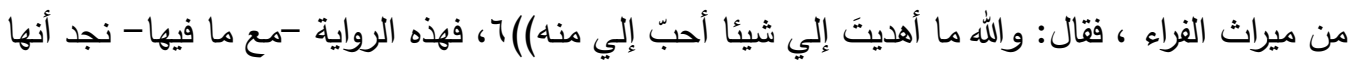
تُعبِّر عن نظرة القدماء لهذا السفر الخالد. 
إن النص يعذّ الأساس في استنباط الأحكام الفقهية فضلاً عن غيرها ، وقد تعددت طرقه عند

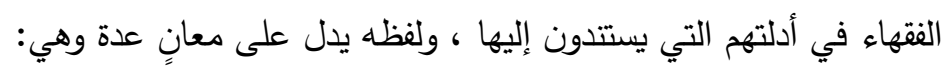

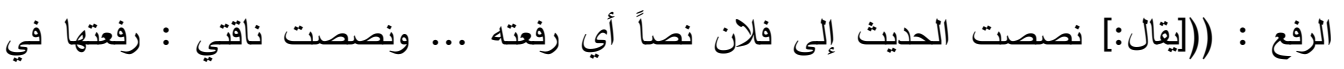

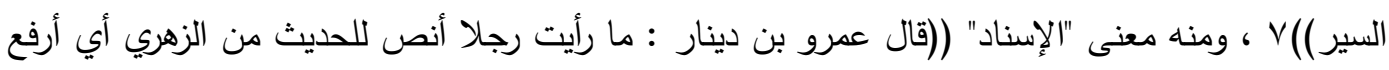
له وأسند ـ يقال : نص الحديث إلى فلان أي رفعه ، وكذلك نصصته إليه . ونصت الظبية الظبية جيدها :

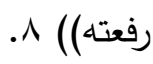

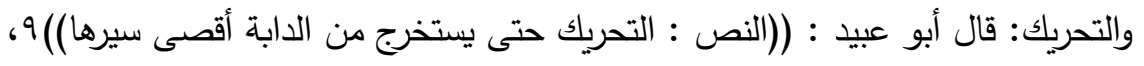

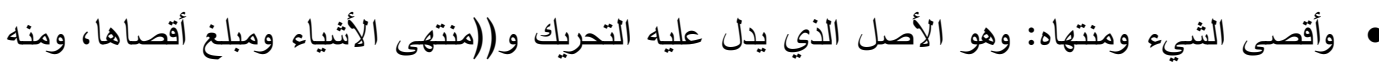

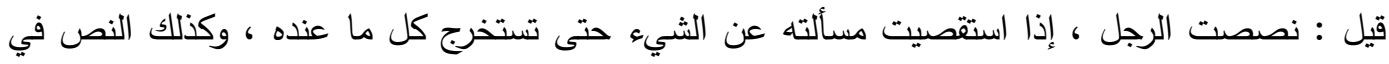

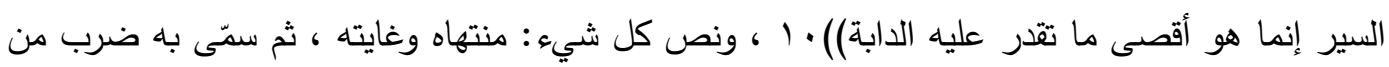

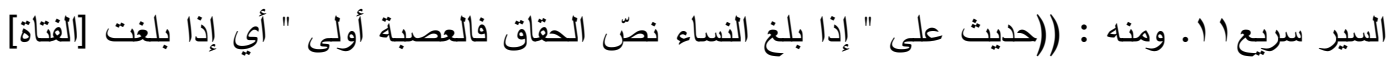

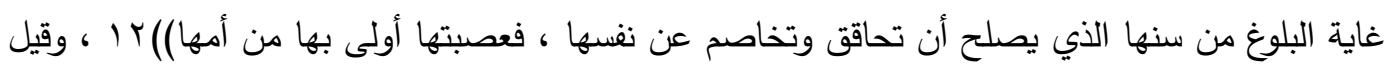

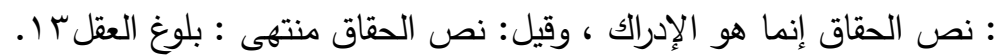

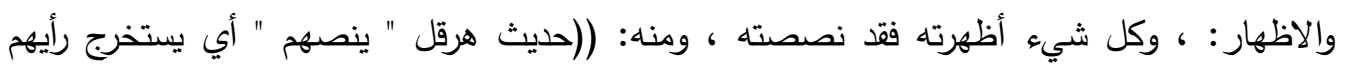

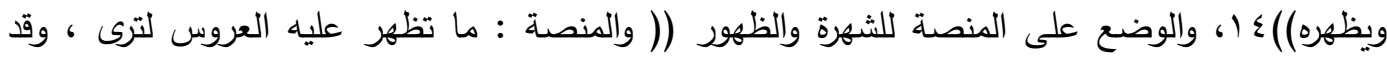
نصها وانتصت هي ، والماشطة تنتص عليها العروس فتقعدها على المنصة ، وهي تتنص التص عليها لترى من

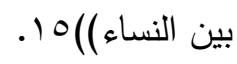
وارتفاع الصوت : نقل الزبيدي : ((نصّ الثواء ينص نصيصا من حد ضرب : صوت على النار ، نقله

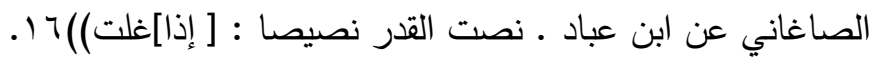

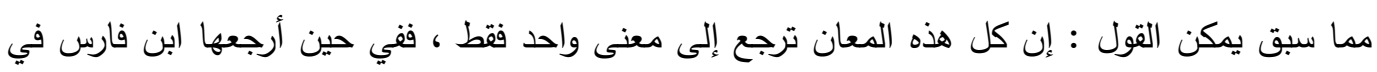

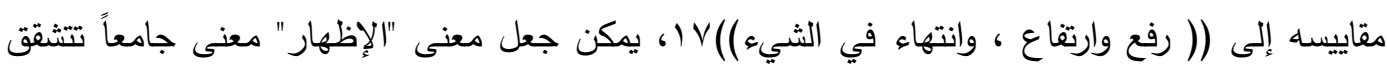

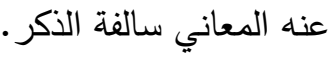


العـــــــد الثلاثون

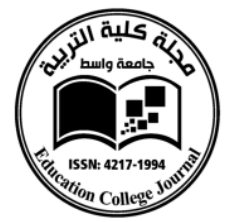

مجلـــة كليـــة التزبيــة

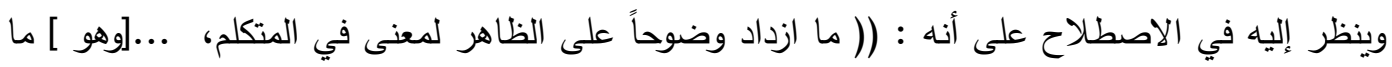

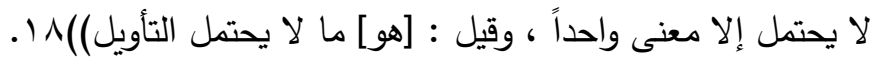

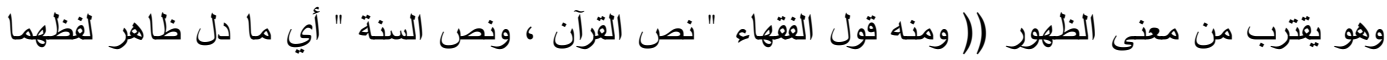

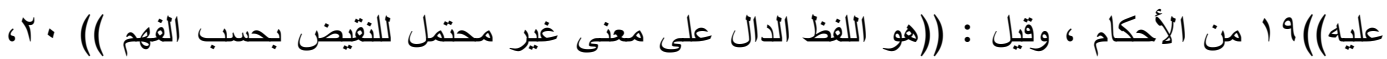

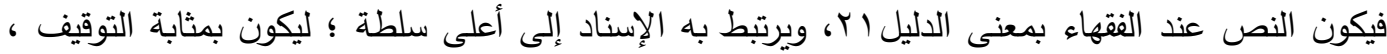

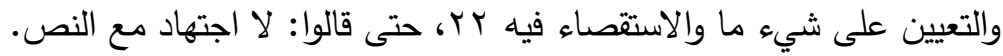

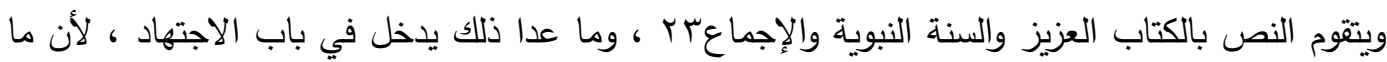

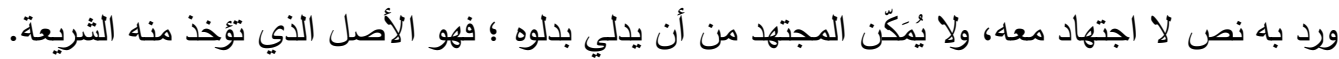
$(r-1)$

يُنظر إلى (القرآن الكريم) بوصفه نصاً ودليلاً من أدلة الأحكام الواقعية عند الفقيه ؛ لأنه ((كتاب الله

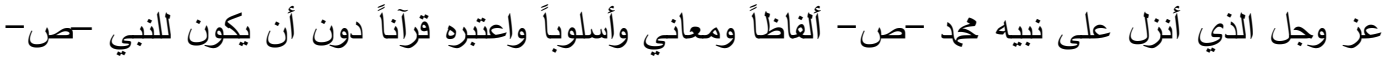

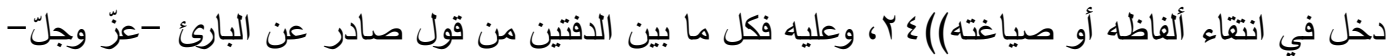

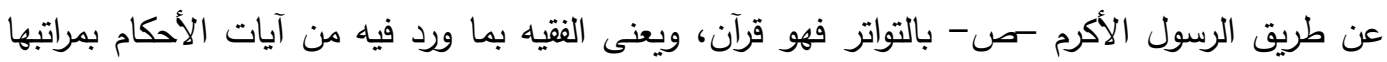

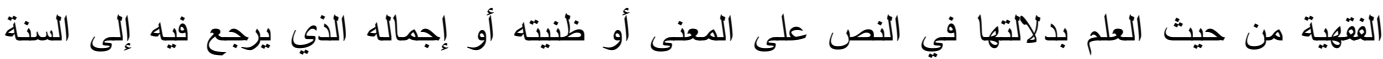

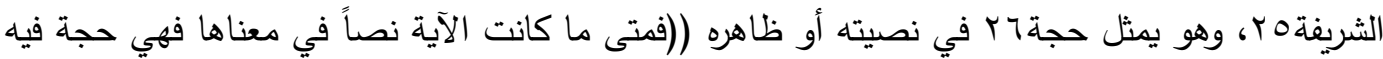

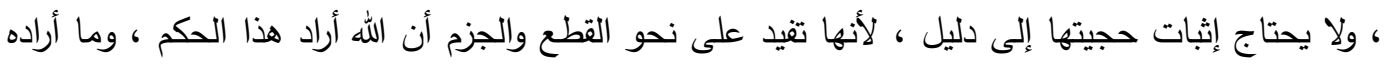

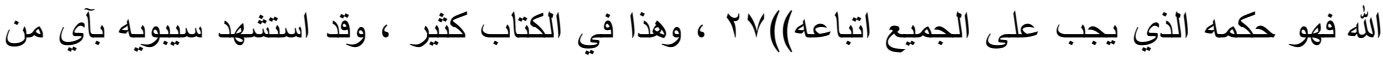

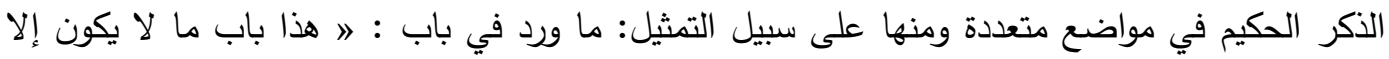

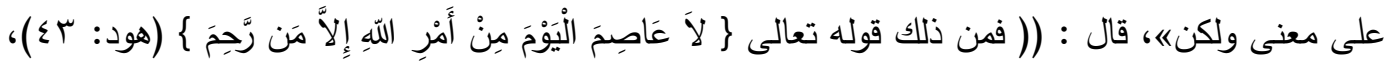

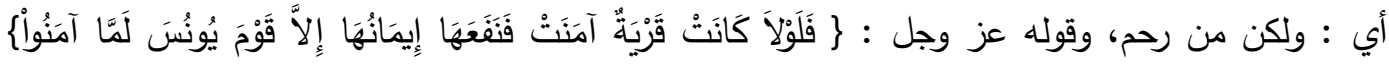

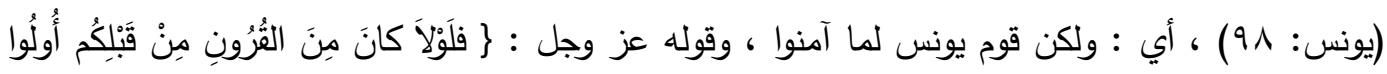

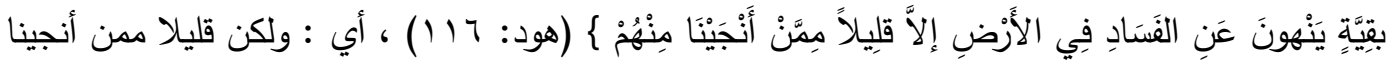

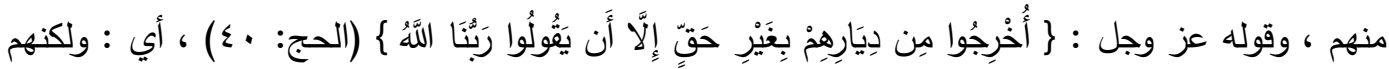

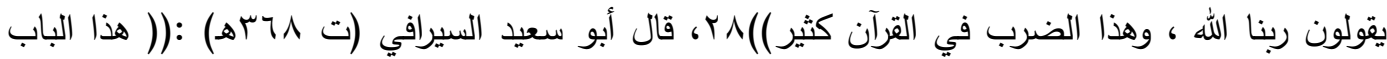

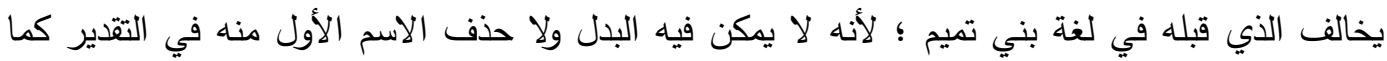

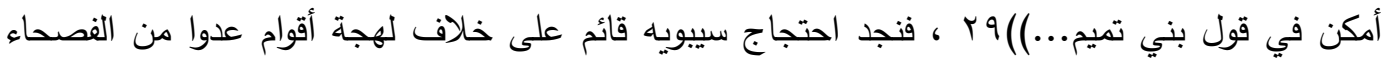

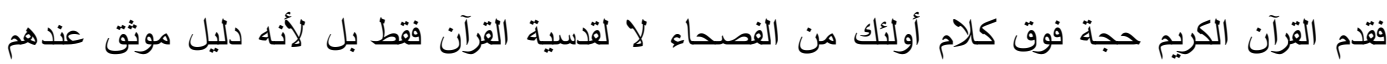


ودونه كل الفصحاء، أما القول بعنايته لأصحاب المعاني بهذا الجانب من النظر إلى الذكر الحكيم فهو من خطل الكلام ؛ لأن التأليف في منهجية هذه المصنفات قائم على استقصائه وبيانه لغوياً ، بمعنى إن القراءة

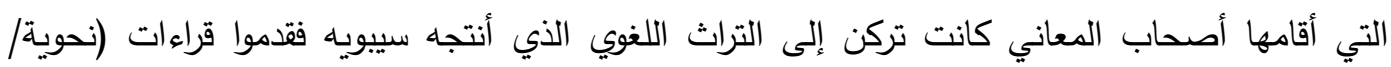

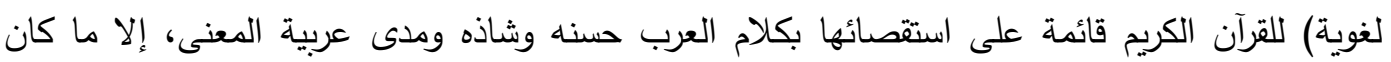

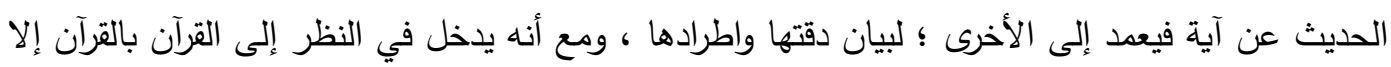

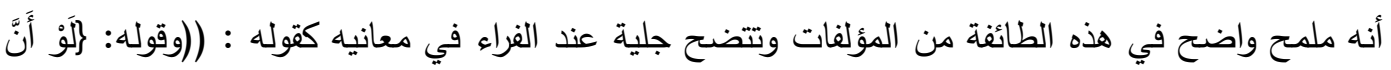

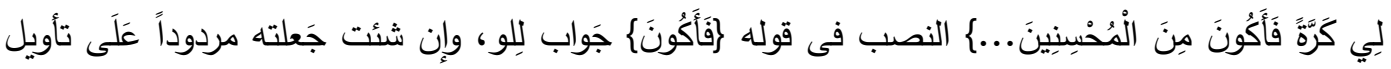

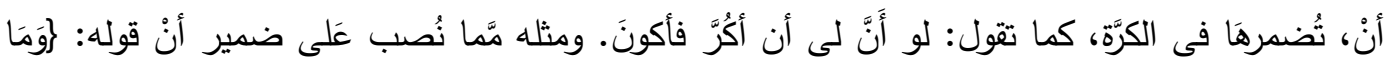

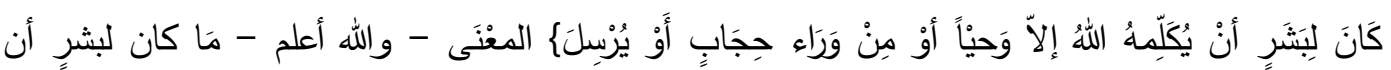

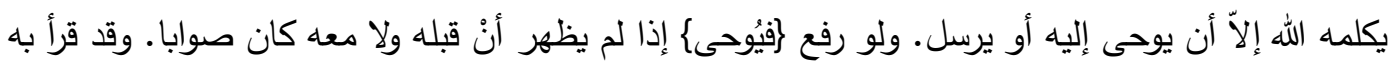

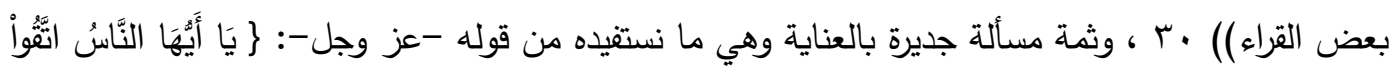

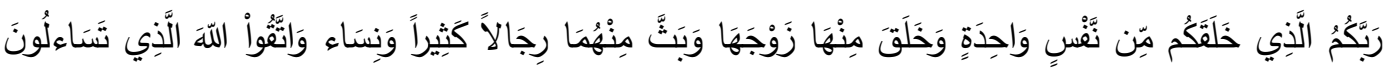

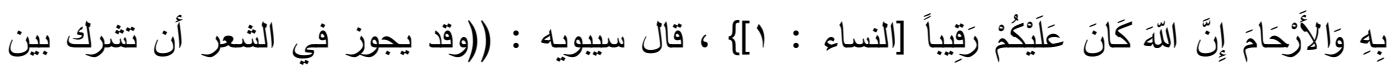

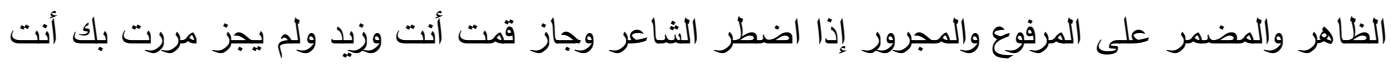

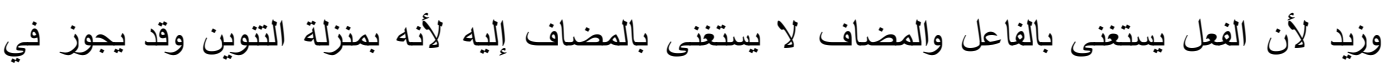

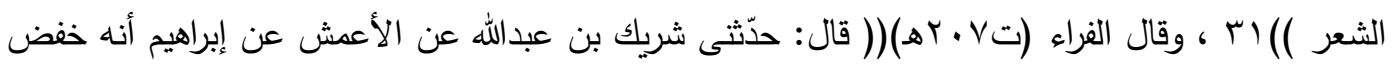

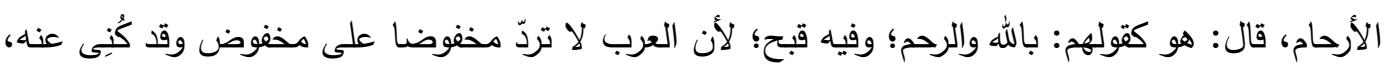

وقد قال الثاعر فى جوازه:

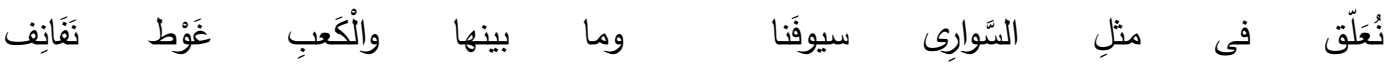

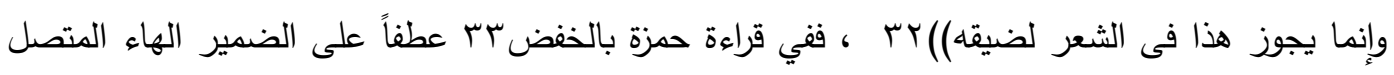

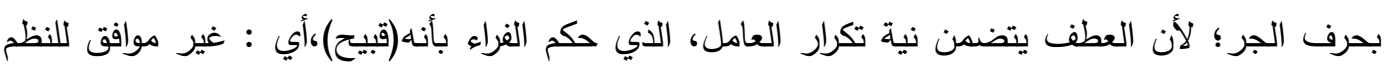

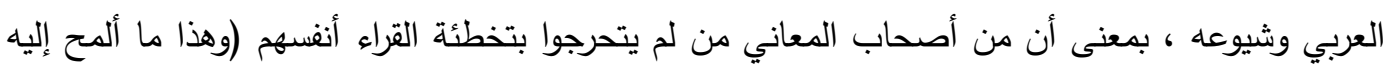

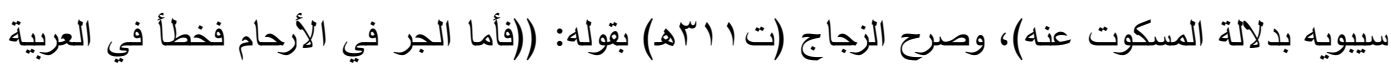

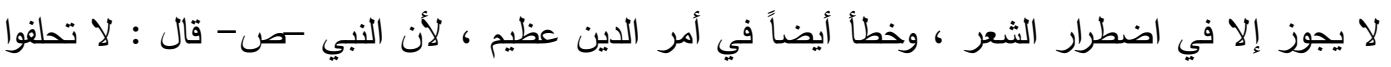

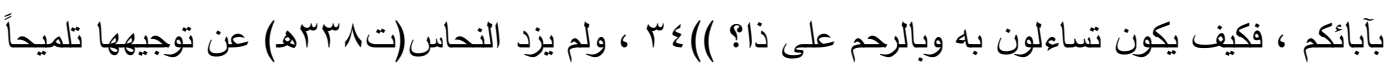

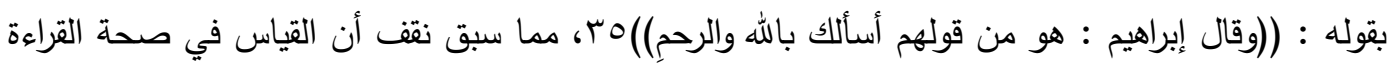

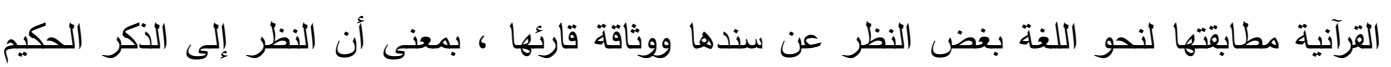




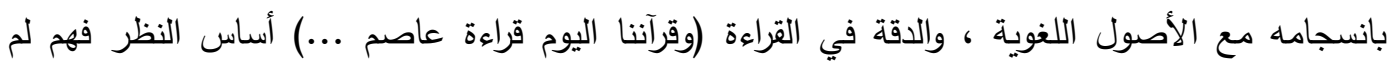

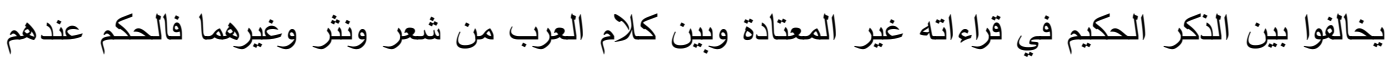

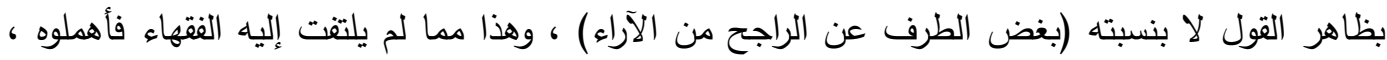

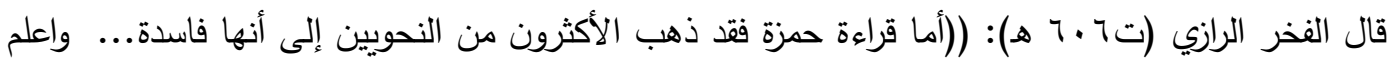

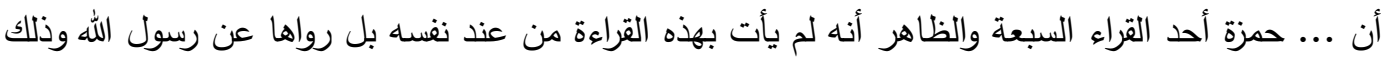

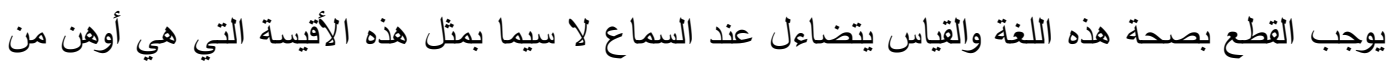

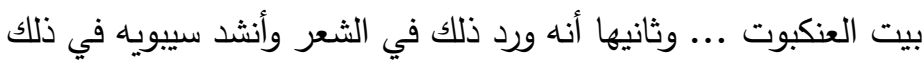

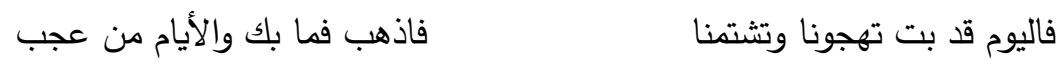

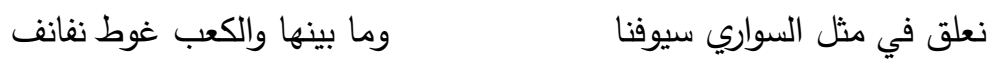

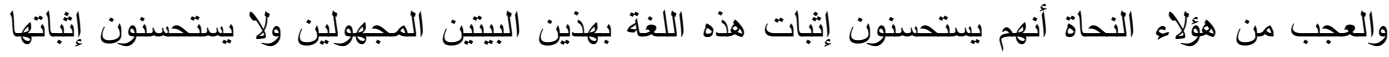

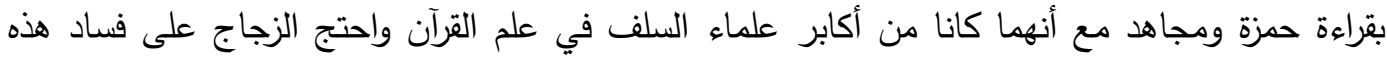

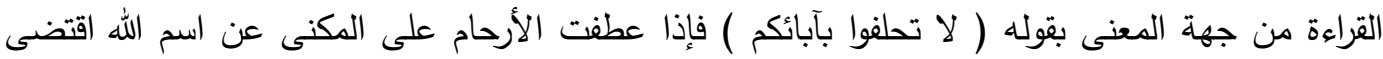

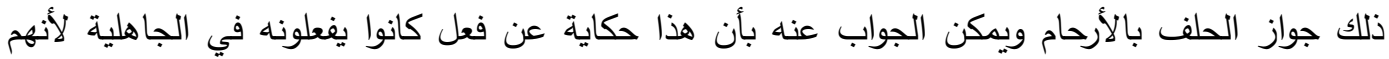

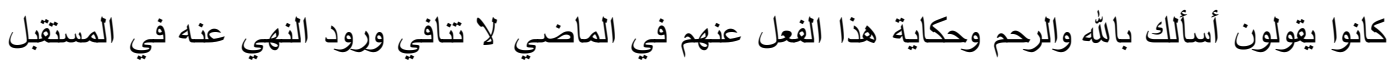

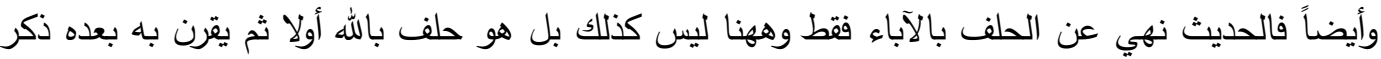

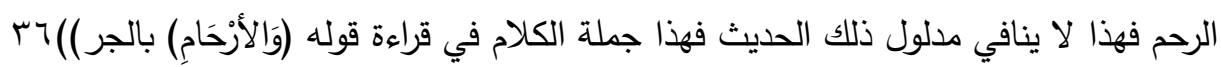

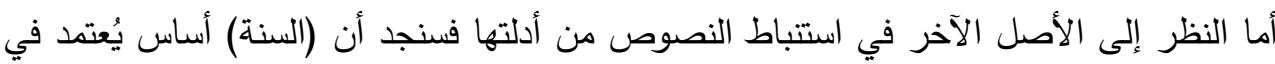

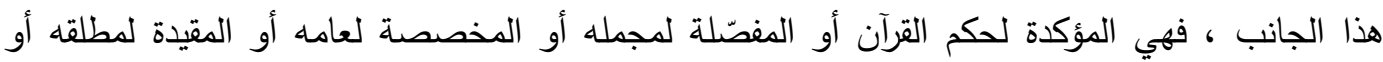

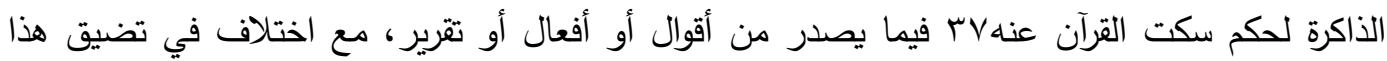

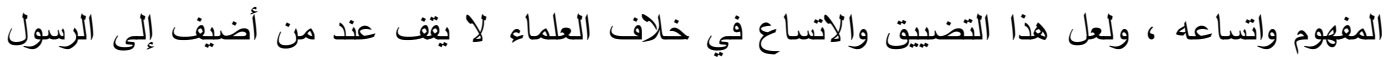

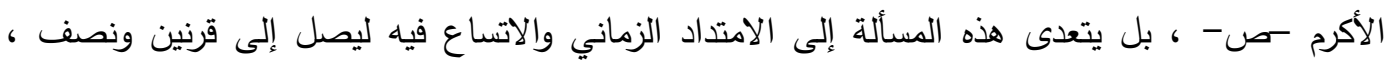

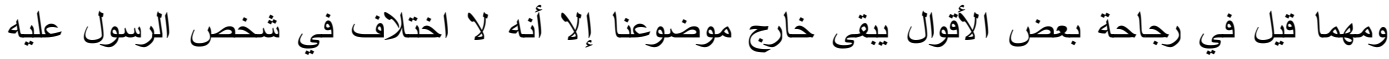

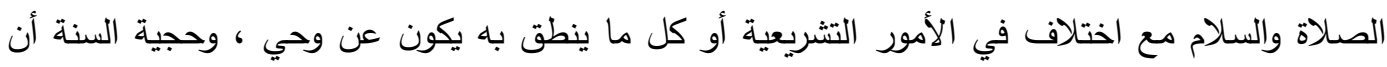

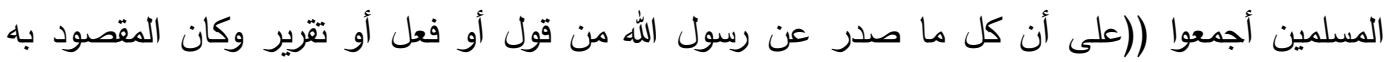

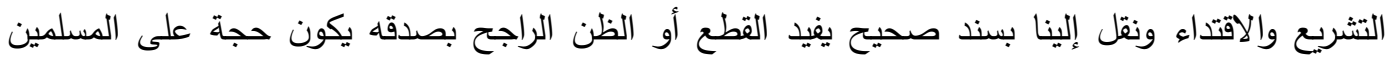

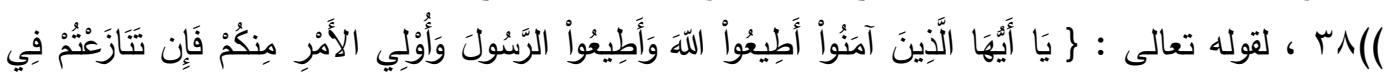




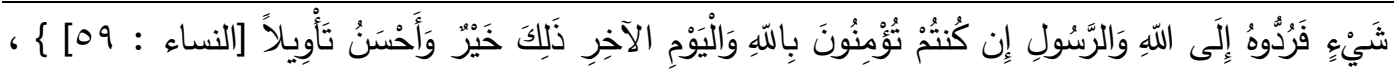

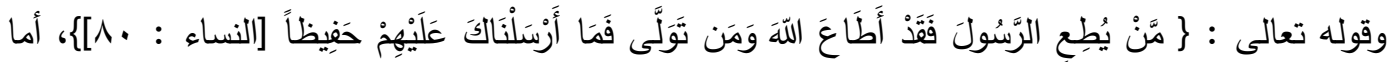

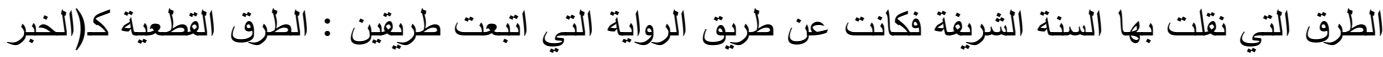

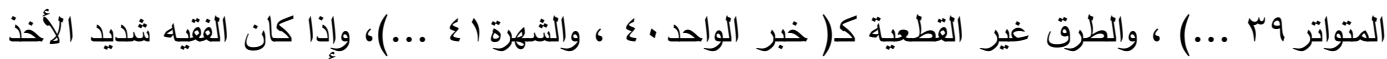

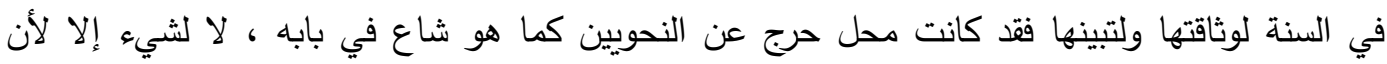

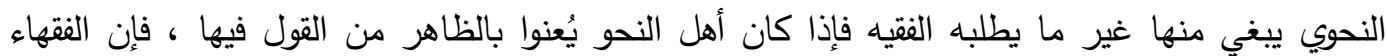

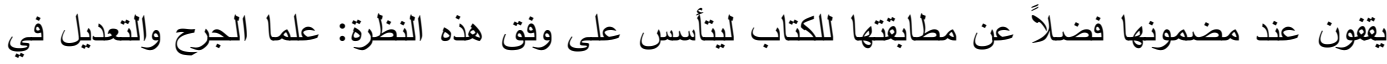

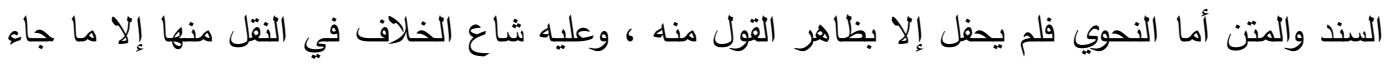

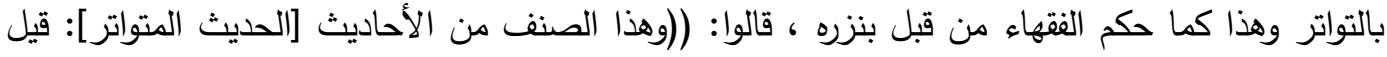

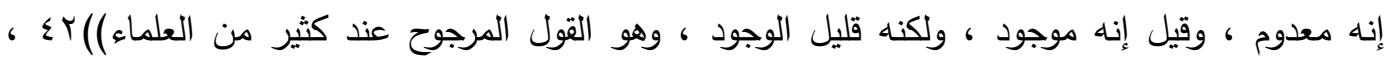

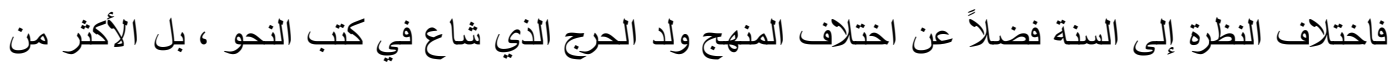

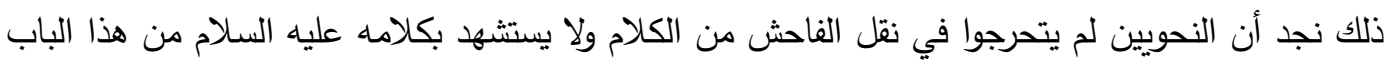

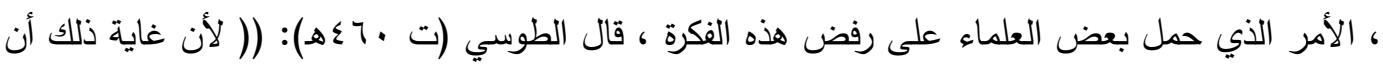

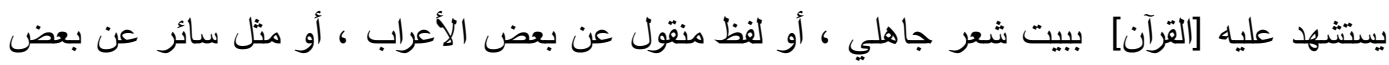

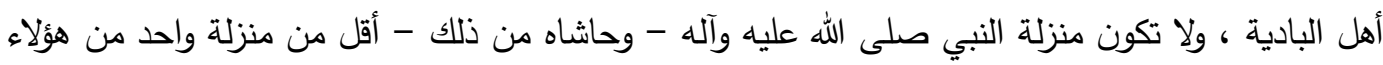

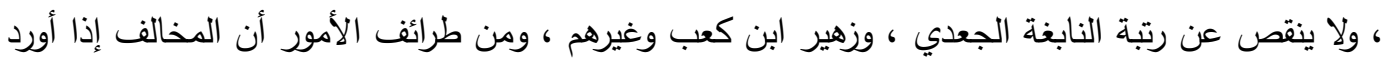

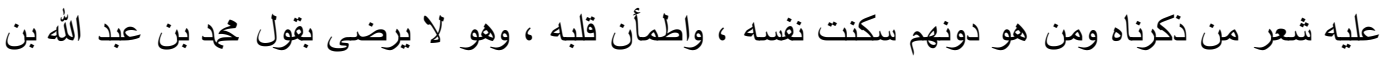

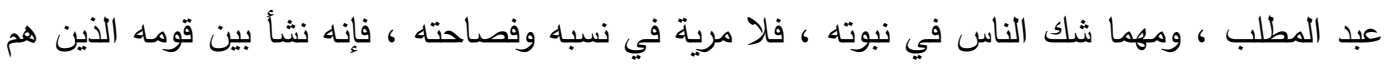

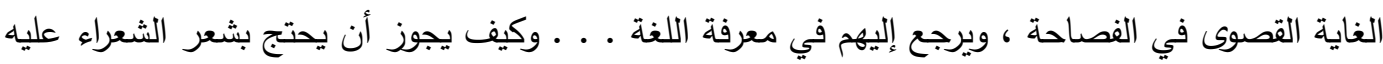

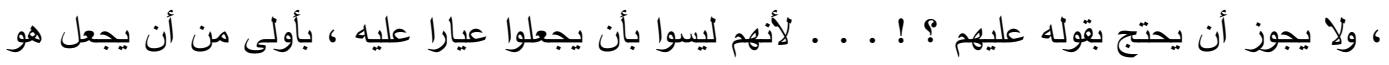

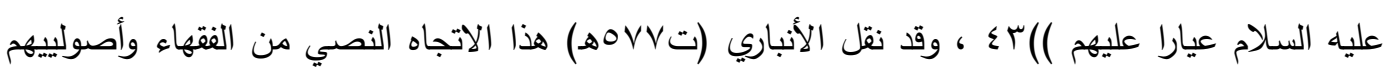

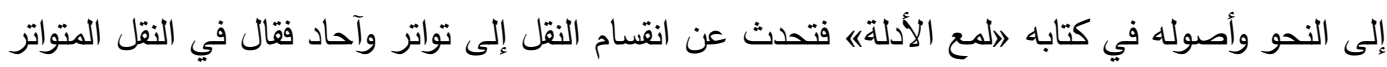

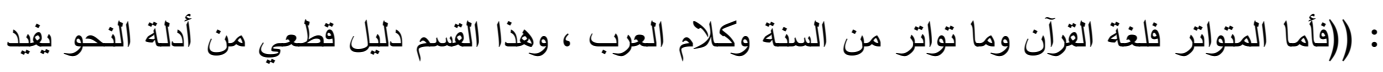

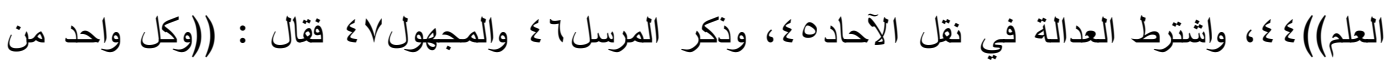

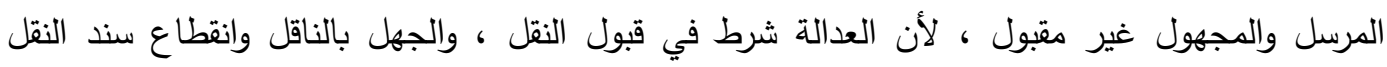

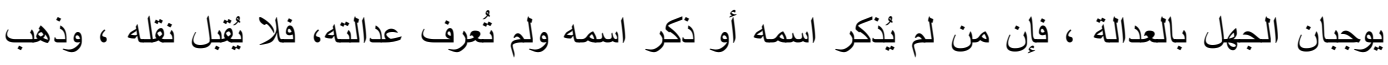

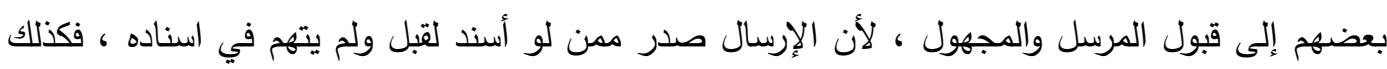


العـــــــد الثلاثون

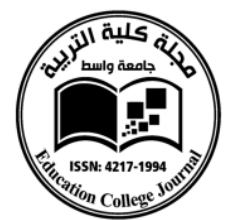

\section{مجلـــة كليـــة التربيــة}

في ارساله ؛ فإن التهمة لو تطرقت إلى إرساله لتطرقت إلى إسناده وإذا لم يتهم في إسناده فكنلك في

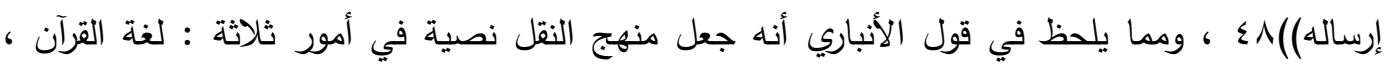

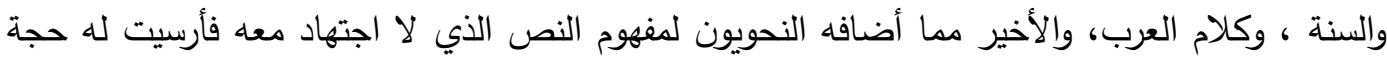

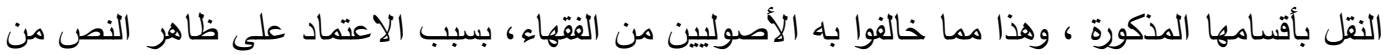

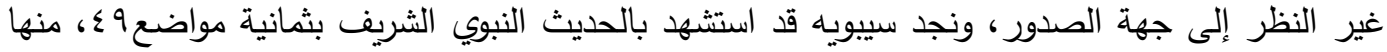

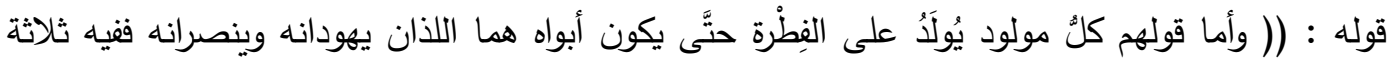

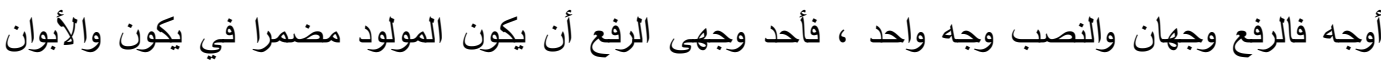

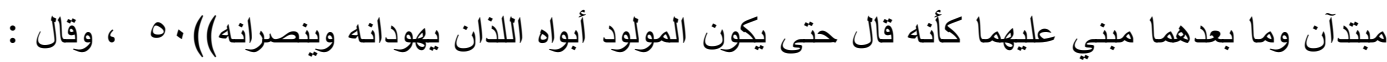

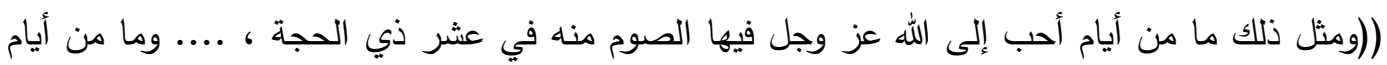

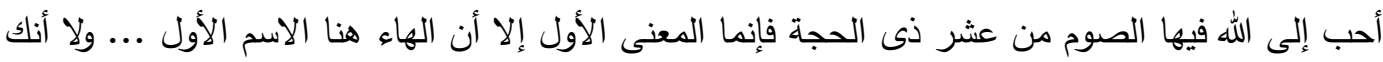

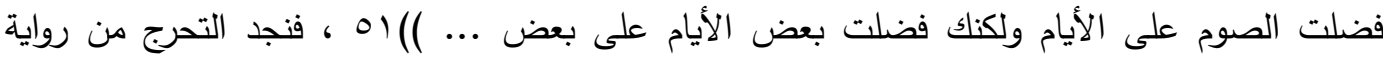

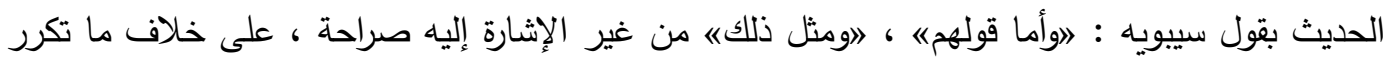

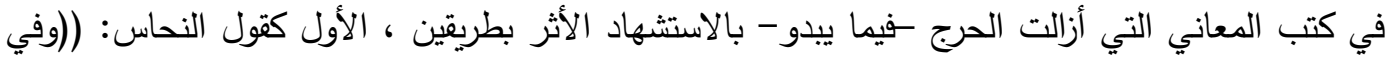

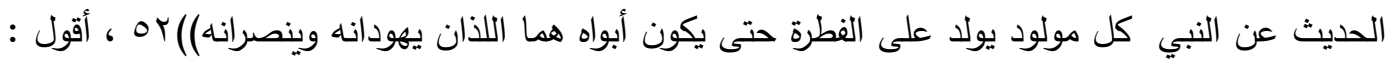

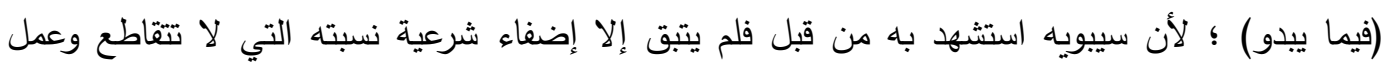

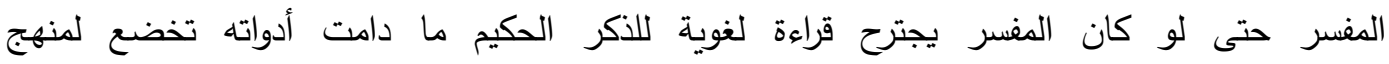

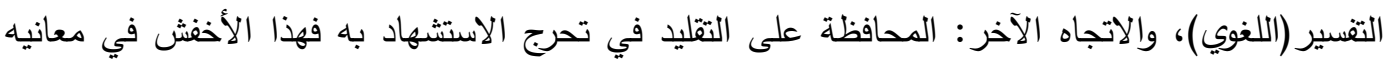

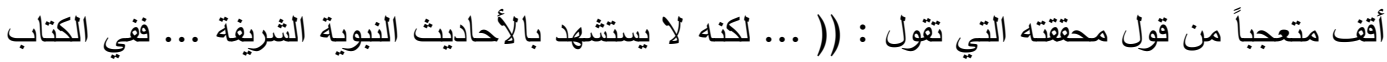

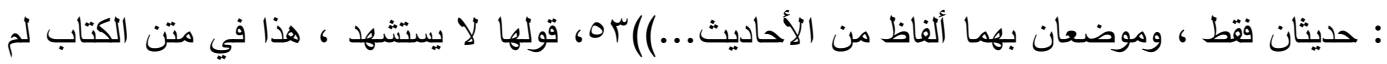

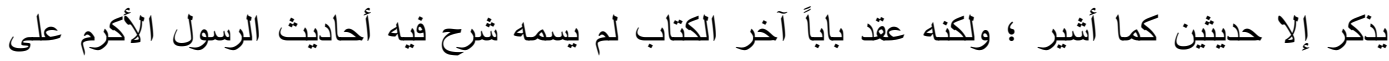

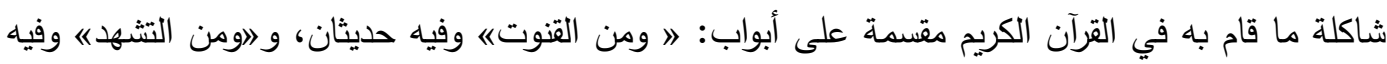

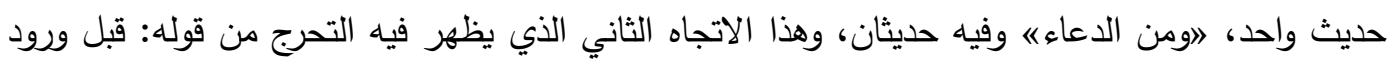

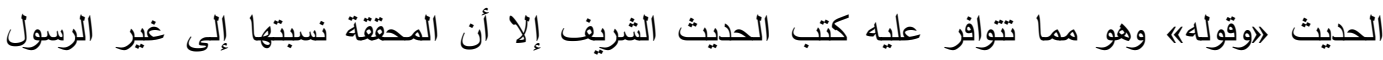

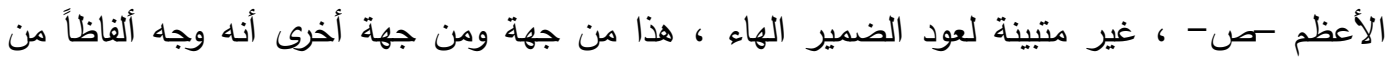

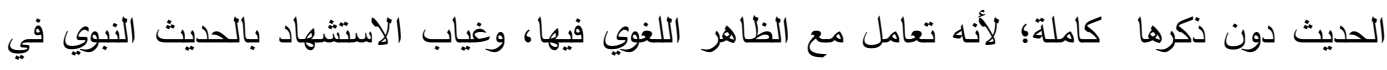
مرحلة التأسيس يصدر عن رواية الحديث واختلاف العلماء في نصه أو معاناه، فضلاً عن أمور أخرى. 


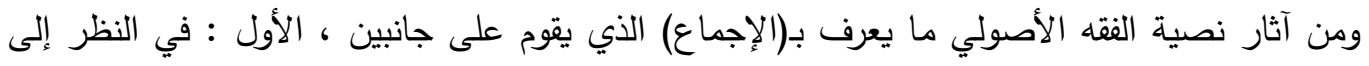

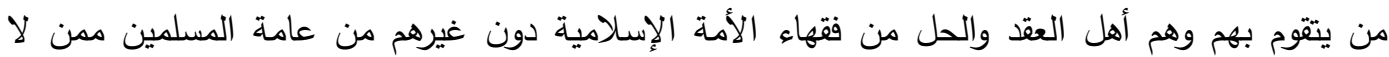

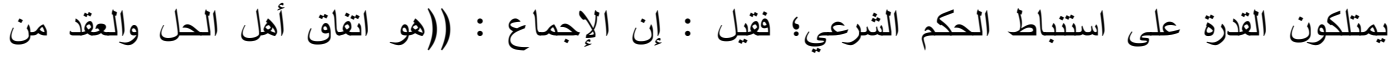

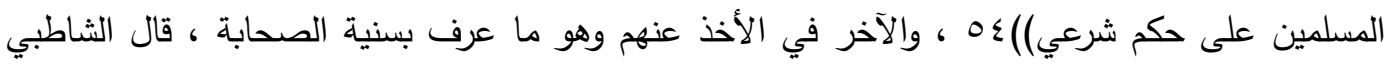

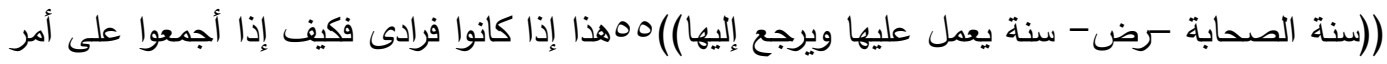

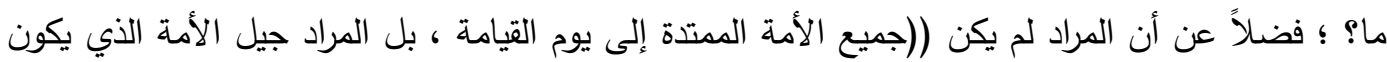

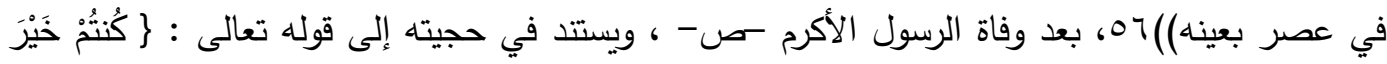

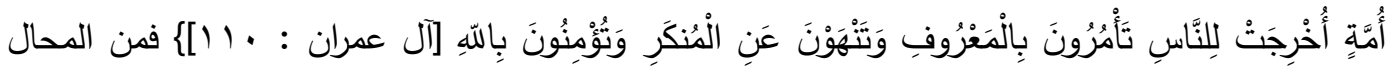

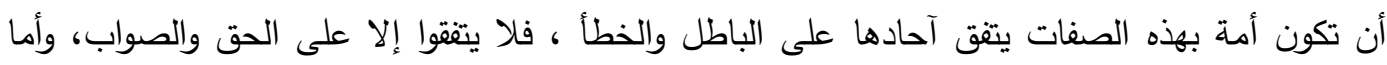

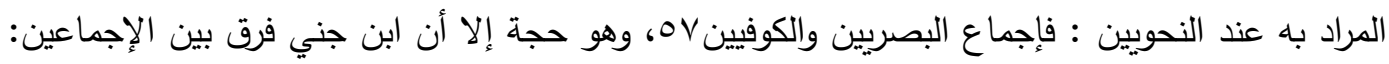

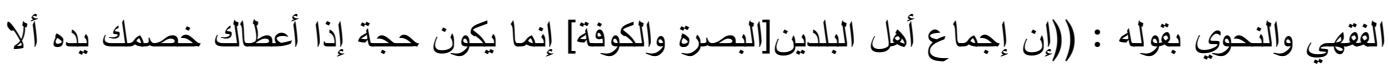

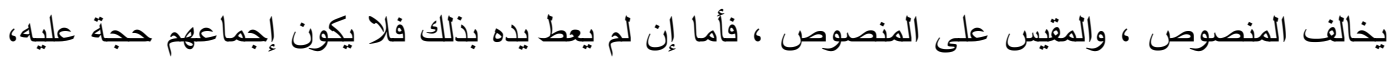

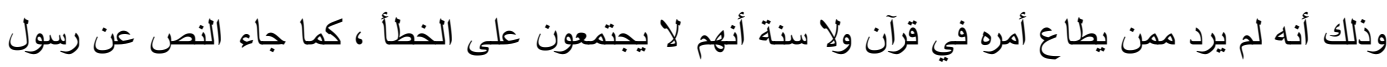

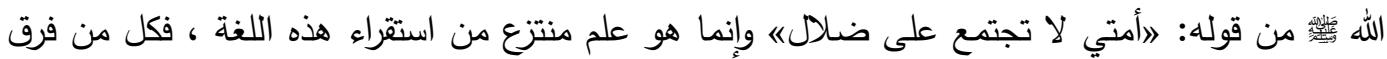

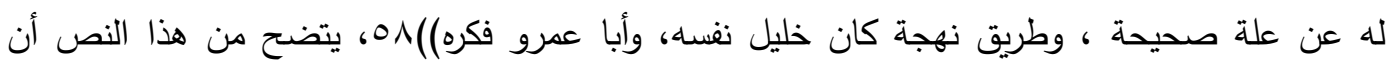

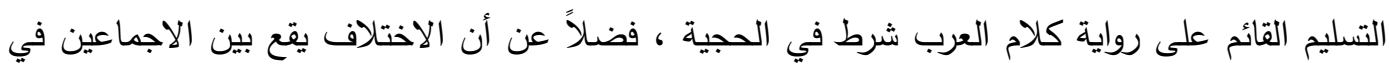

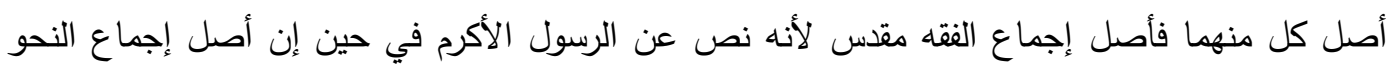

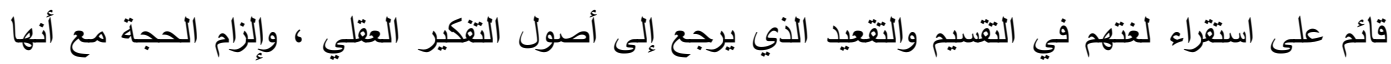

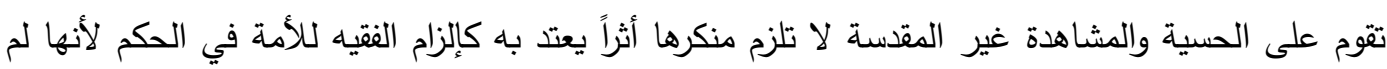

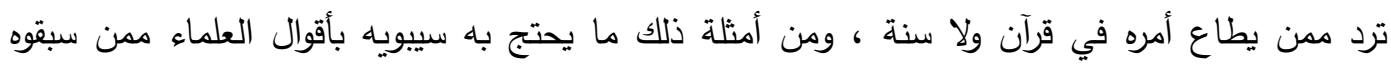

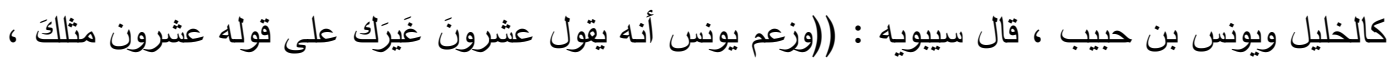

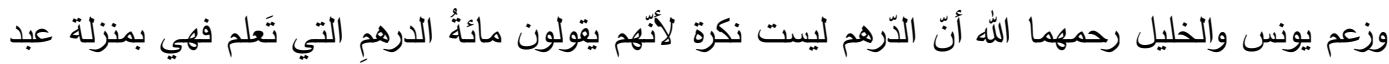

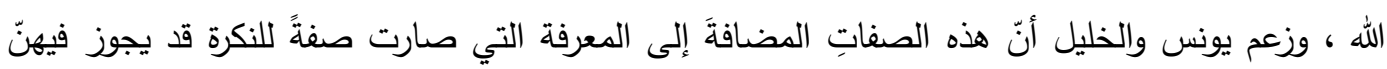

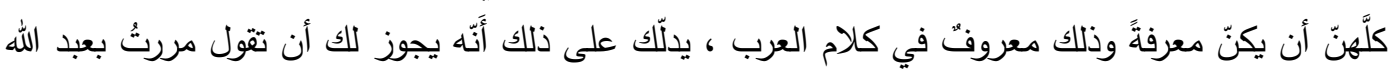

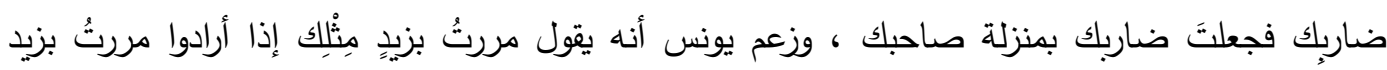

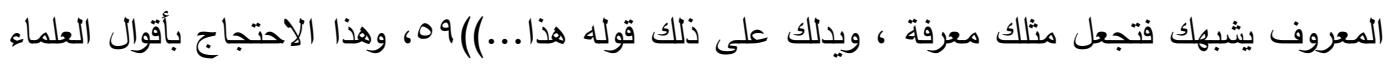

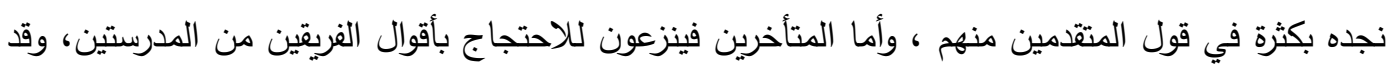




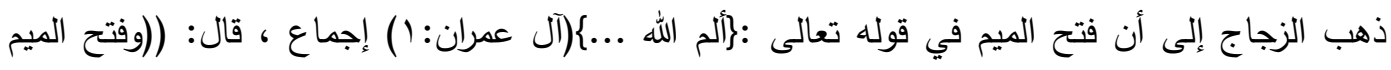

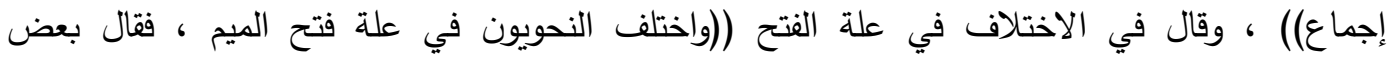

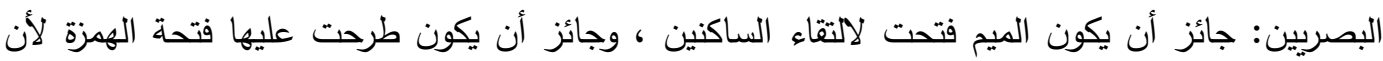

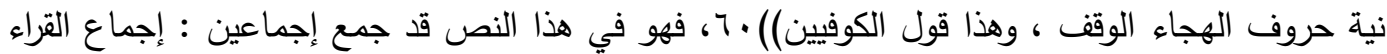

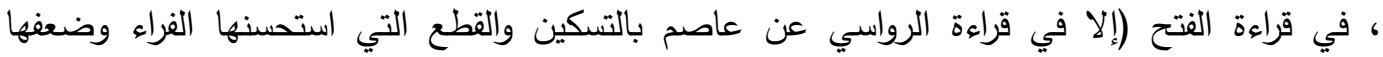

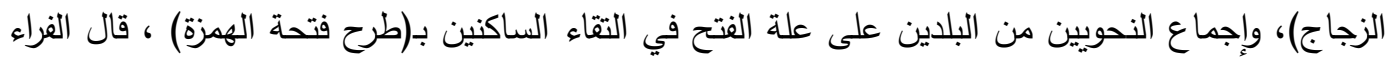

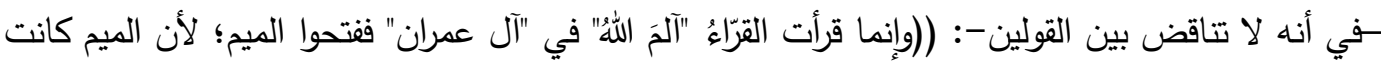

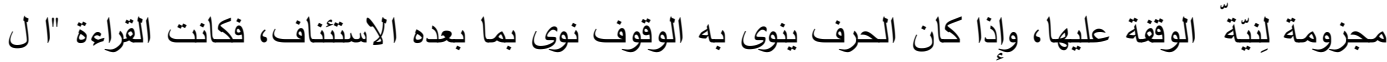

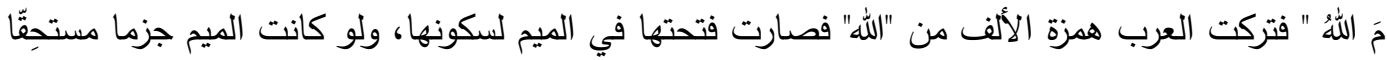

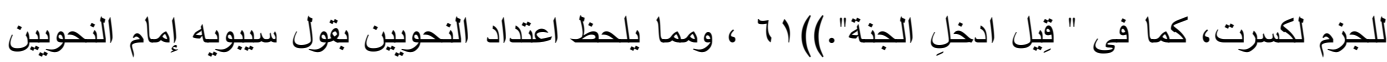

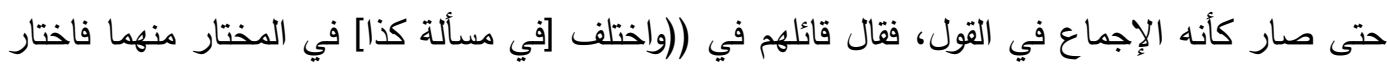

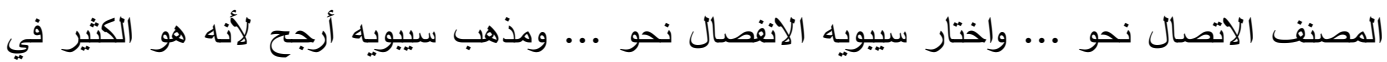

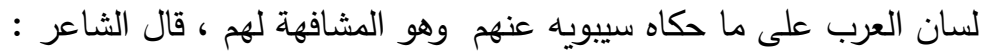

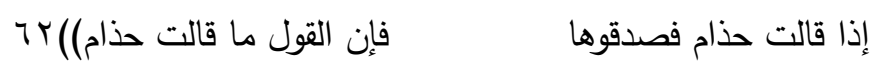

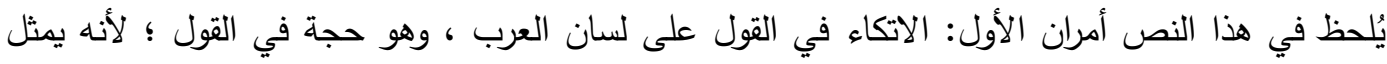

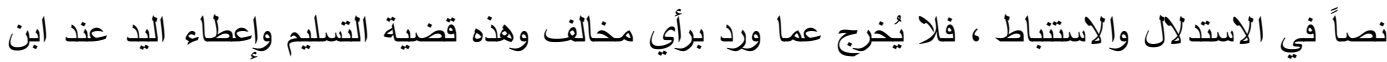

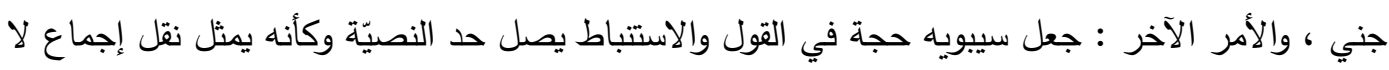

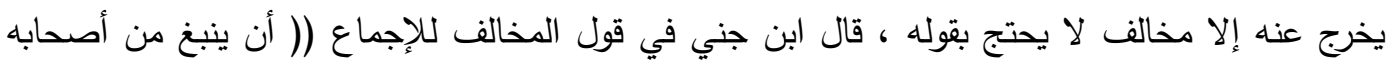

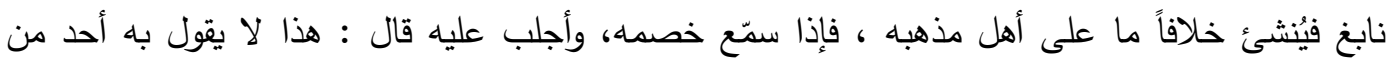

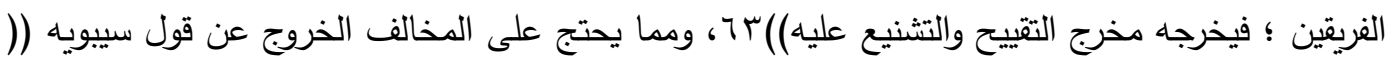

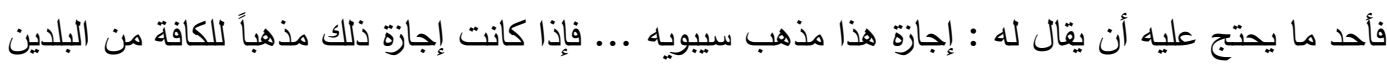

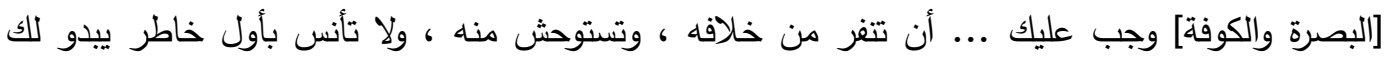

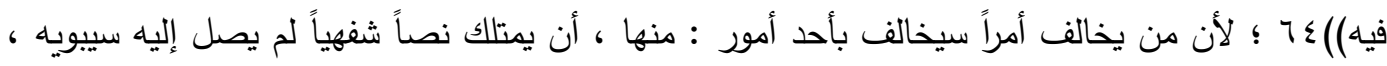

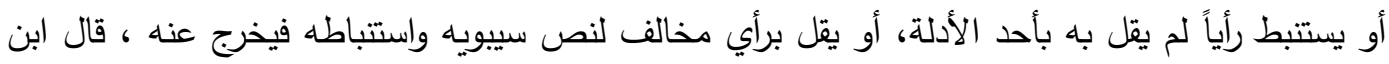

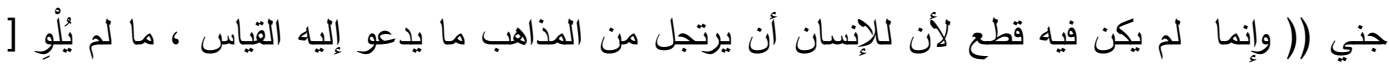

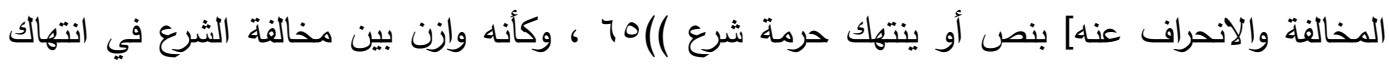
(نص) سيبويه ، على حين نجد شيئًا مشابها لذلك عند النحويين في أخذهم وفي استباطهم وفي استلالهم، 
وهو الأساس الزماني والمكاني الذي يعتمدون عليه في أدلتهم : القبائل وسط الصحراء التي لم تتأثر

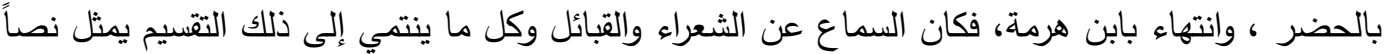

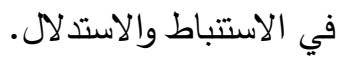

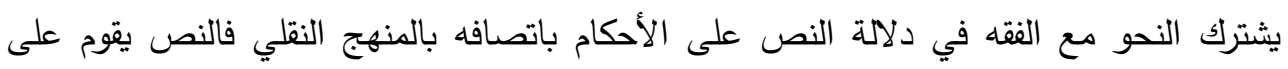

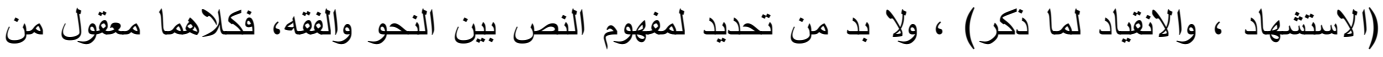

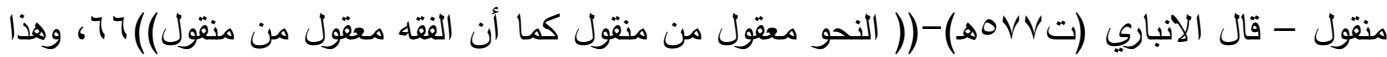

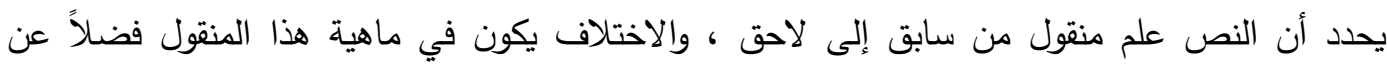

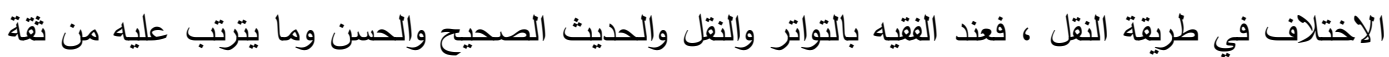

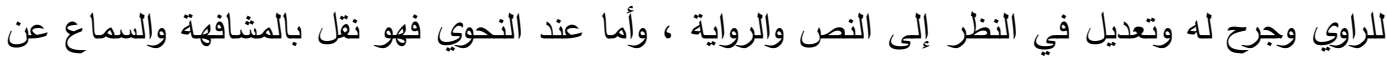
الأعراب والفصحاء منهم بمعياري الزمان والمكان؛ فالمشترك بينهما أن كلا الأصلين المعتمين هما: بـ(النقل)، مع اختلاف في الماهية ، واختلاف في التعامل معله . ففي النظر إلى ماهية النص الفقهي نتبين أنه نص إلهي مقدس لا يمكن المساس التعاس دعه به أو اهماله بأي طريقة

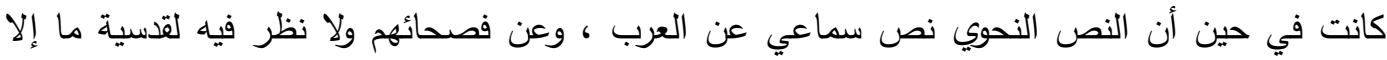
الصحة والوثاقة ، وهو بذلك أقل شأناً من النص الفقهي في مسألة القداسة والثأن ؛ لأنه كلام بشر فضلألاً

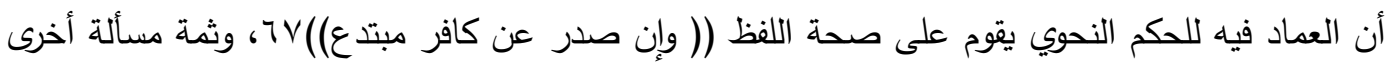

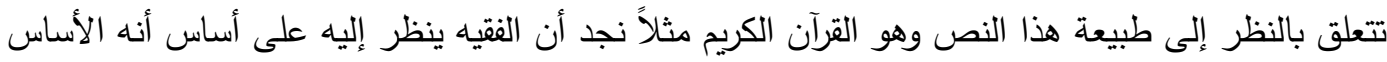

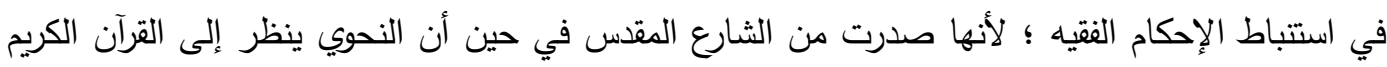

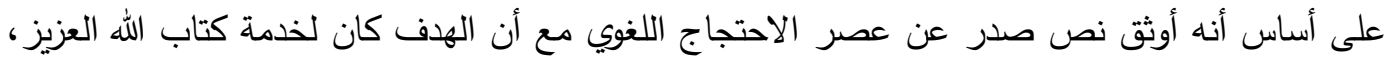

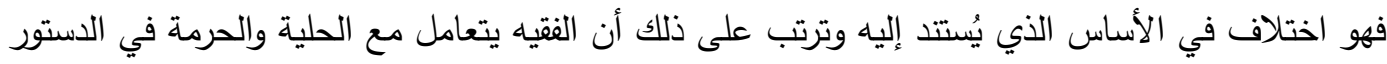

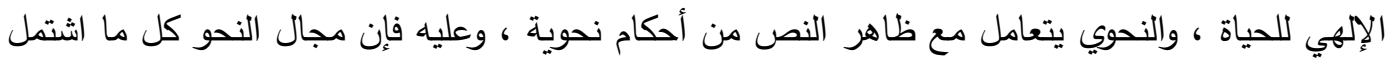
على ألفاظ وأحكام وهو القرآن الكريم كله ، في حين أن مجال الفقيه فيه أضيق ؛ لأنه ارتبط بآيات الأحكام

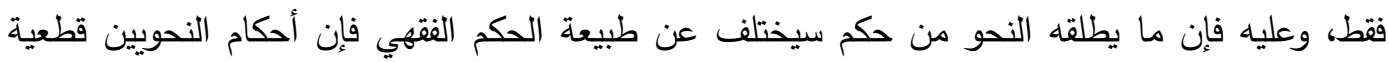

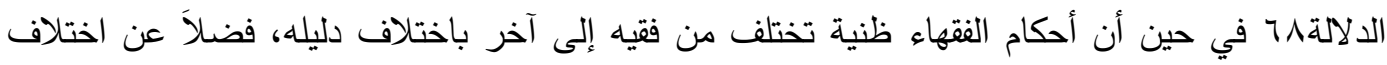
الهدف في كل منهما، ففي الفقه نجد أن هدفه استتباط الأحكام، وفي النحو أن الهدف صون اللهاء الكان عن 
الاجتهاد

$(r)$

\section{مجلـــة كليـــة التربيـــة}

$(1-r)$

إن اختلاف آراء النحويين في المسائل النحوية يدل على اجتهاد ضمن ضوابط ، وقيود خاصة،

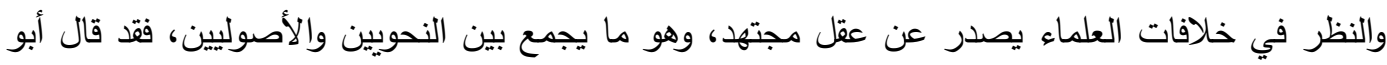

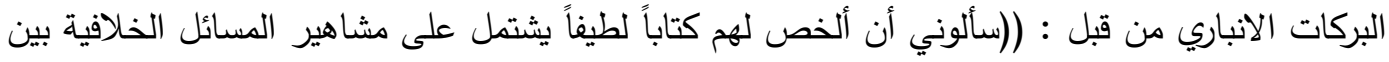

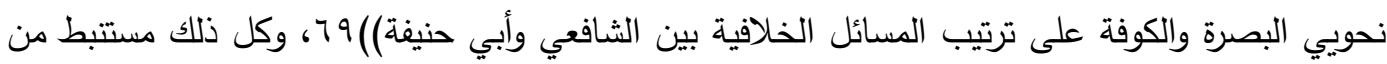

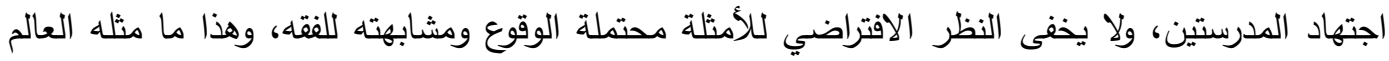

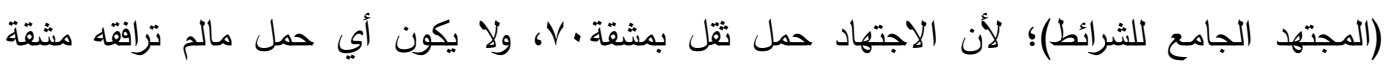

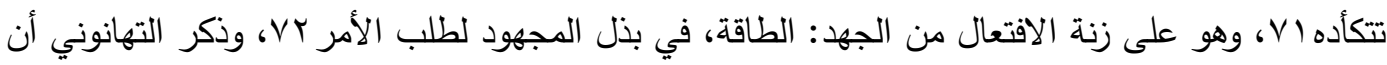

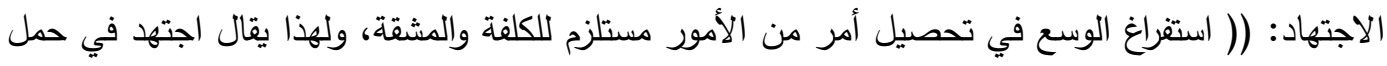

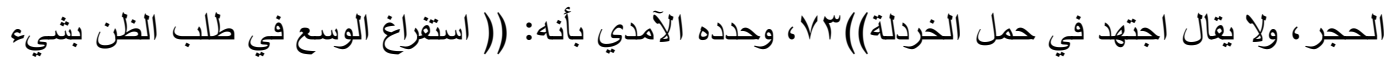

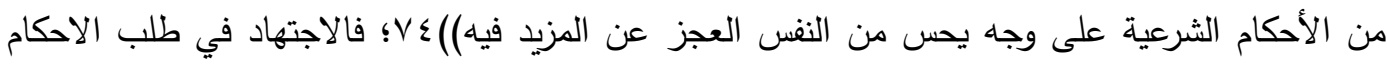

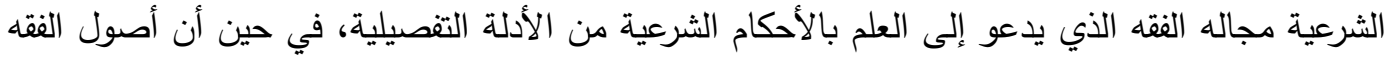

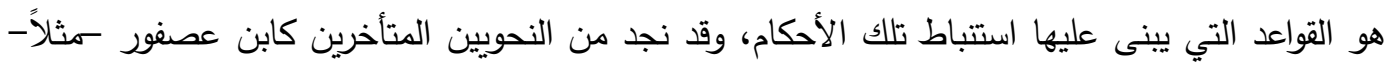
من قيد النحو بأنه: ((علم مستخرج بالمقاييس المستتبطة من استقراء كلام العرب الموصلة إلى معرفة أحكام

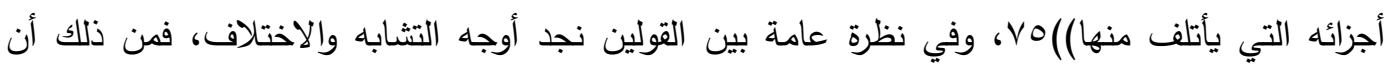

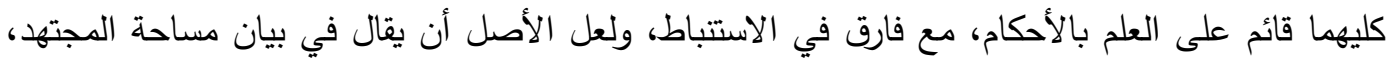

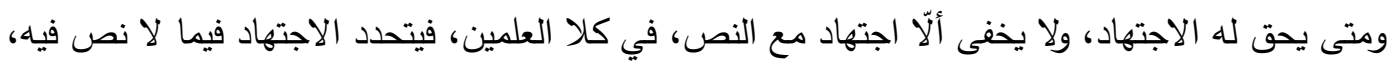

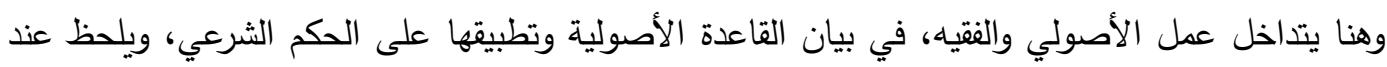
النحوي أن الانطلاق يبدأ من الواقعة النحوية لتأخر الأصول النحوية عن أحكامها سيراً على غرار الفقهاء

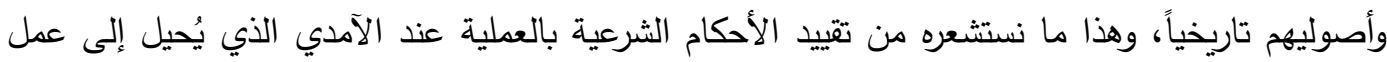

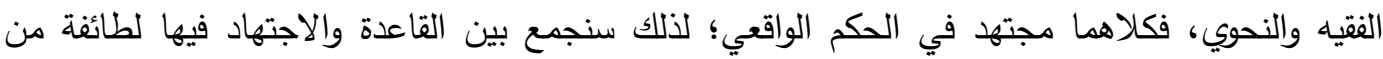

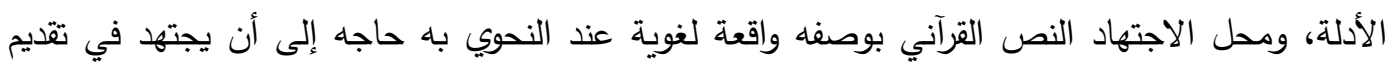
أدلته للوقوف على الحكم النحوي الذي يرى، وقد ينتج -هذا الأمر - خلافاً نحوياً. 
وثمة ملحظ قائم على الاجتهاد، وهو التفريق بين اجتهادين أحدهما مقيد بأصول الشريعة، والآخر مطلق

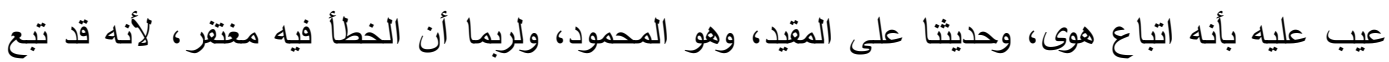
أسساً، فأجها دونها، فلم يسعه جهده إلا بما استطاعه، وتتييد المجتهد العالم والفقيه والنحوي ينطلق من قراءة

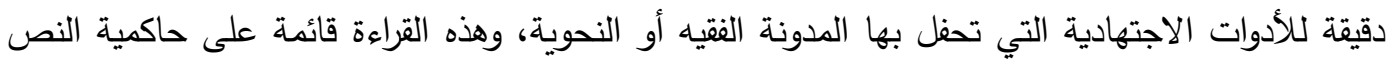

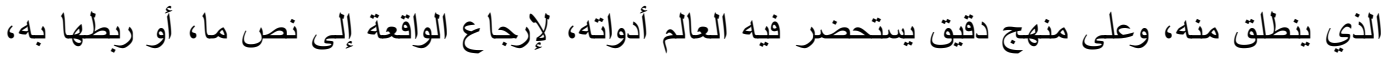

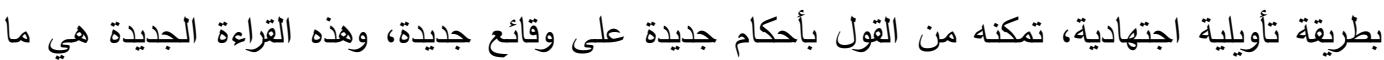

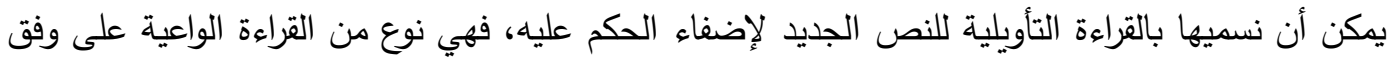

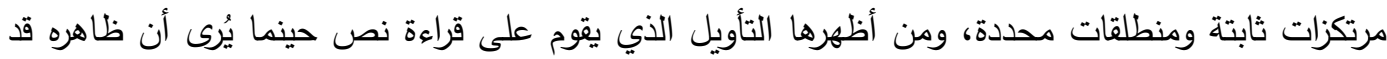

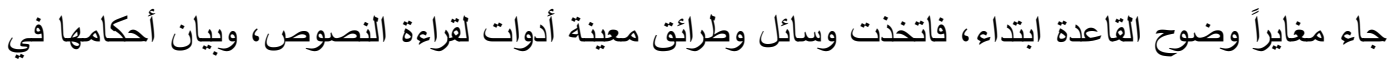

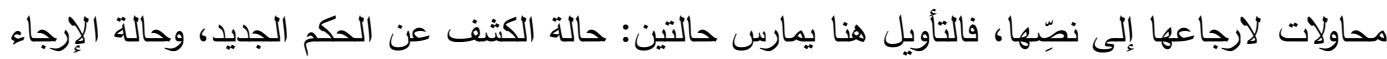

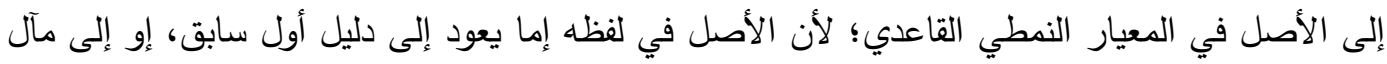

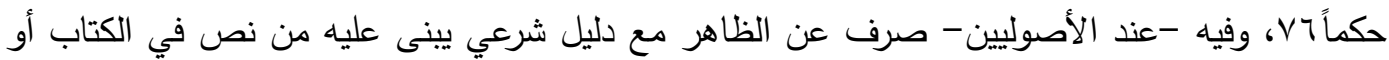

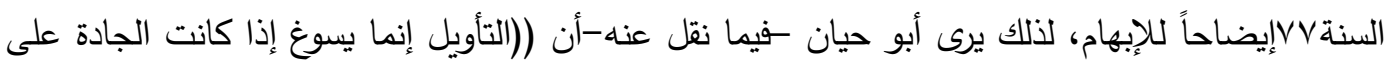

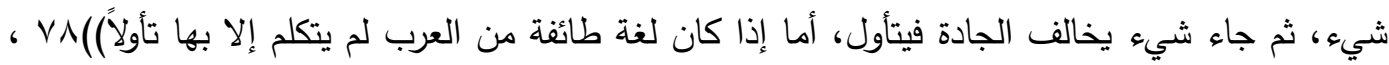

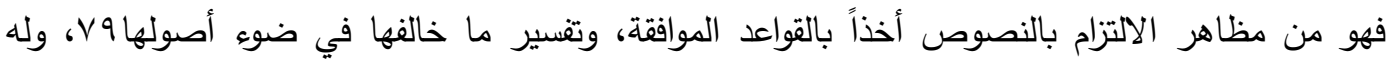

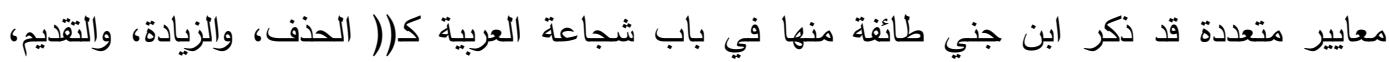

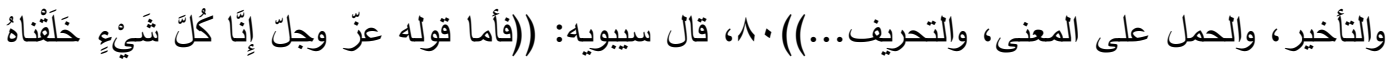

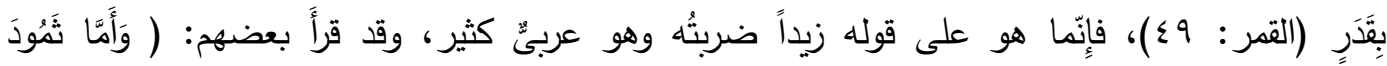

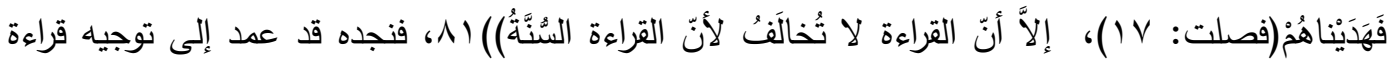

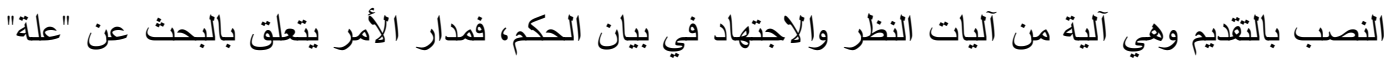

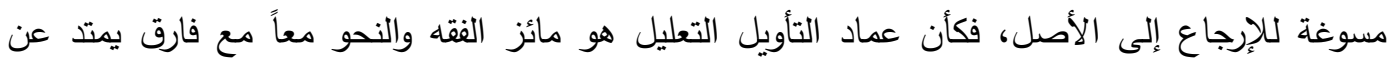

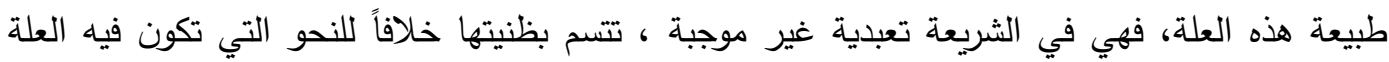

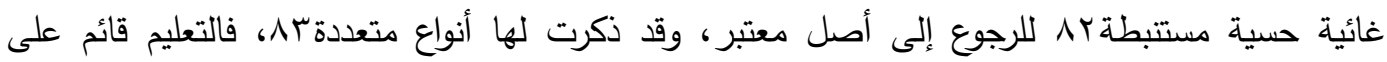

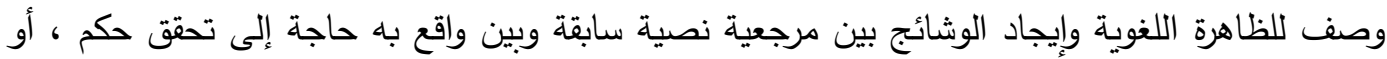
تقديم تقسير لساني له. 
قيل إن (( النحو معقول من منقول كما أن الفقه معقول من منقول))ءی، ويدلل هذا على أنَّ النحو اجتهاد كالفقه فكلاهما معقول بما لم يصدر فيه نص، وما دخله العقل اجتُهد في تصور القاعدة فيه

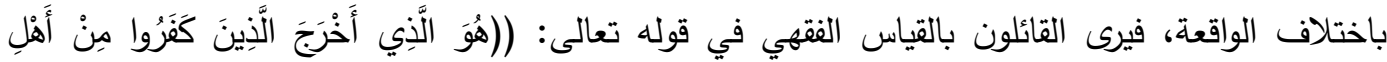

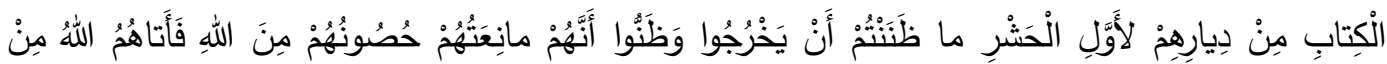

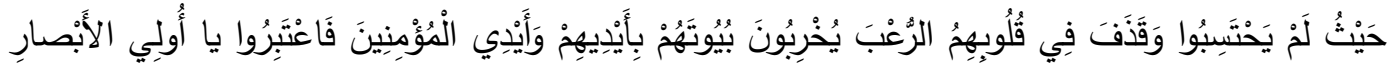

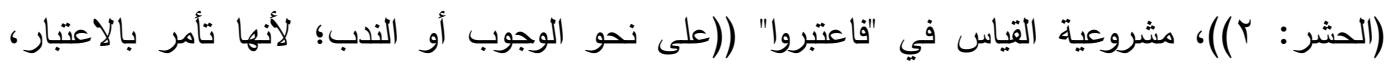

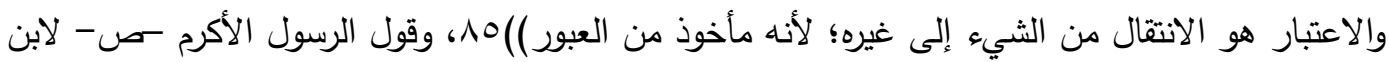

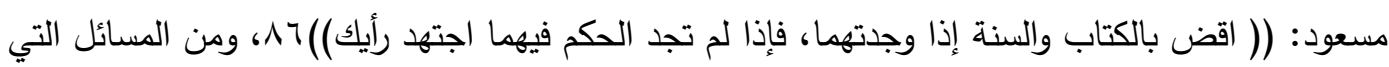

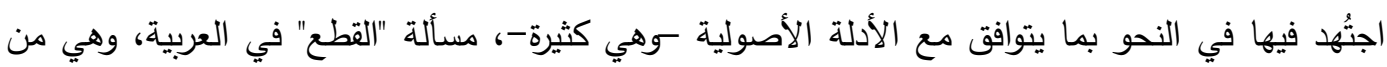

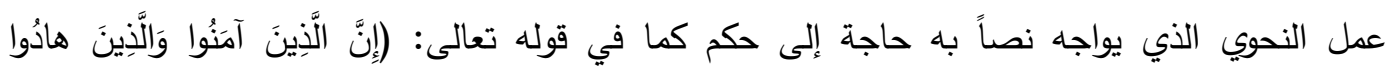

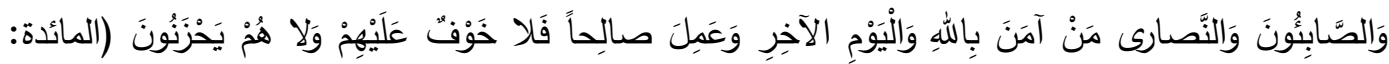

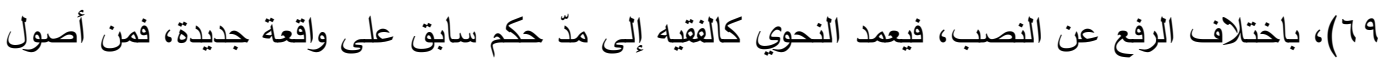

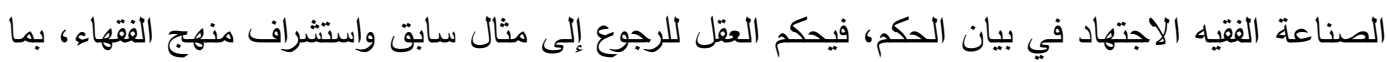

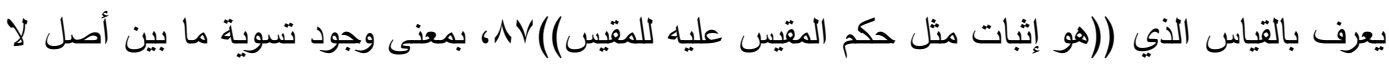

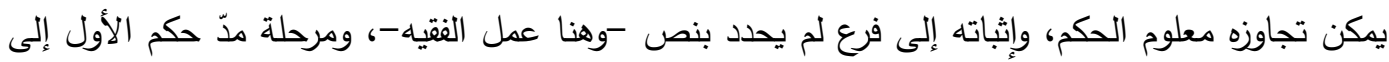

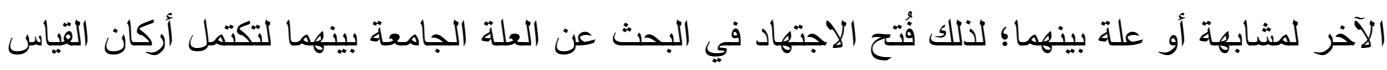

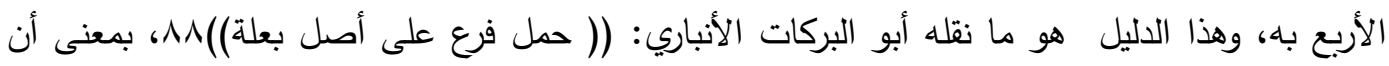

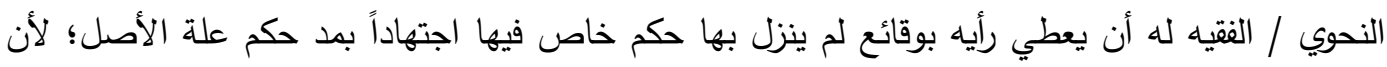

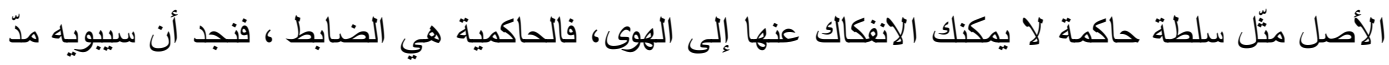

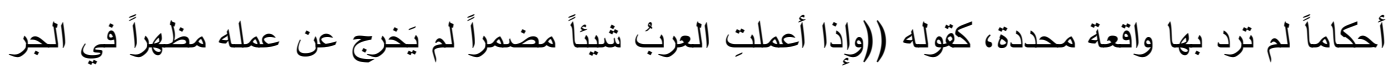

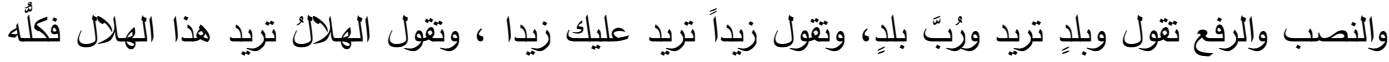

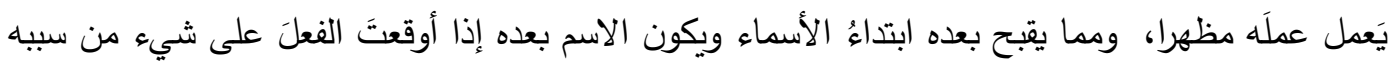

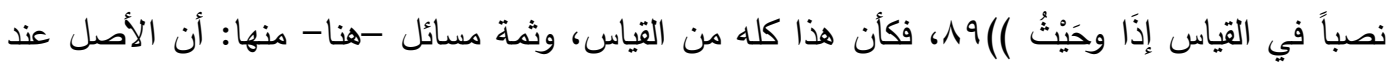

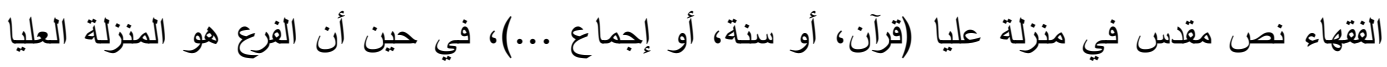

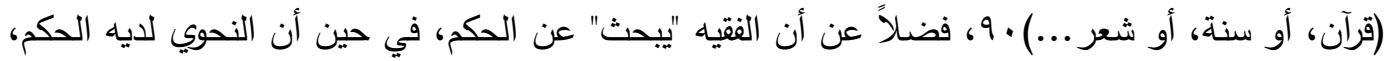
لكن يبحث عن العلة؛ لذلك ما علة النصب فيما سبق، قال سيبويه في ( هذا باب ما ينتصب على انلى التعظيم 
والمدح ) : ((إإن شئت جعلته صفة فجرى على الأول وإن شئت قطعته فابتدأته، وذلك قولك الحمد لله الها

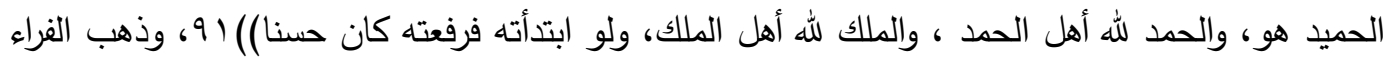

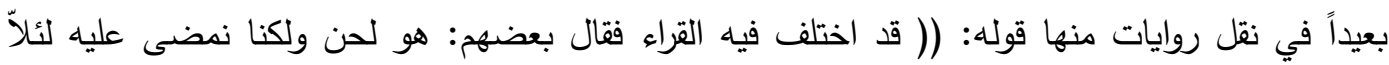

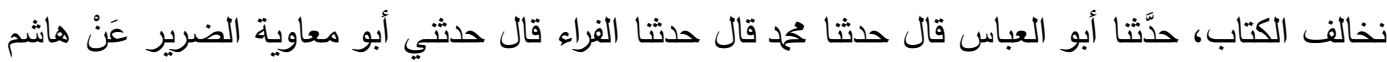

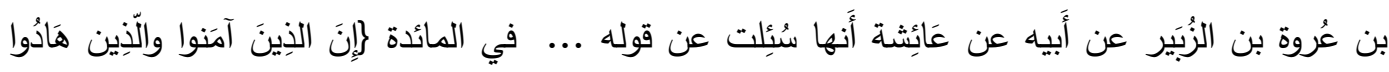

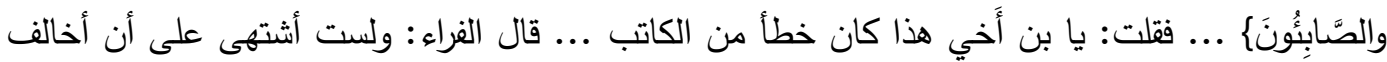

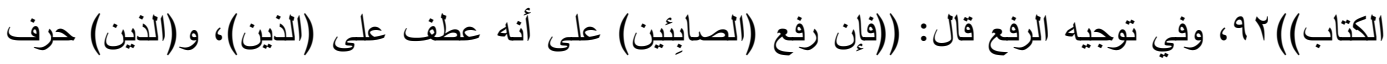

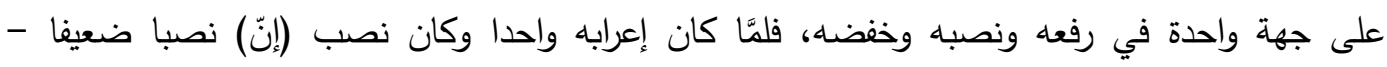

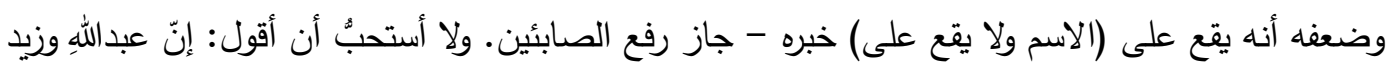

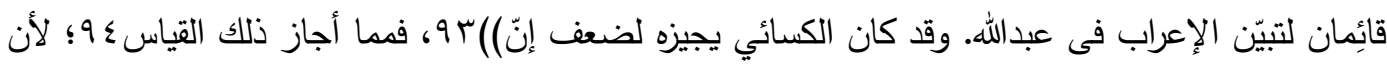

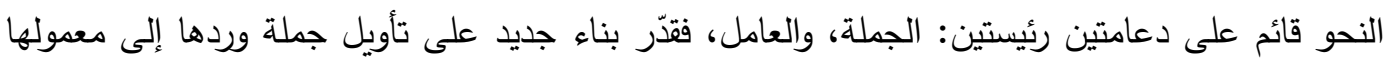

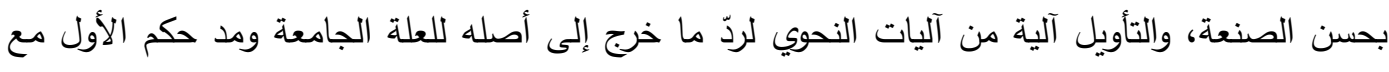

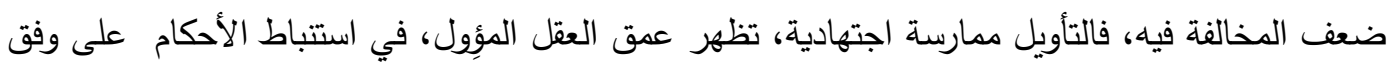
منهج تأويلي واع يرجعها إلى حاكية النص. ومن المناهج التأويلية التي بالمجتهل حاجة إليها في الردّ إلى الأصل: "الاستصحاب"؛ ذلك ألكان أن أبا

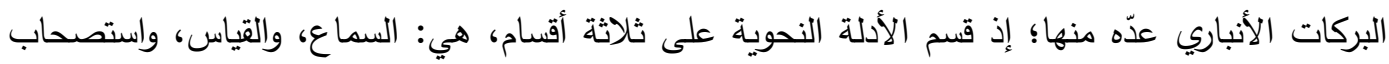

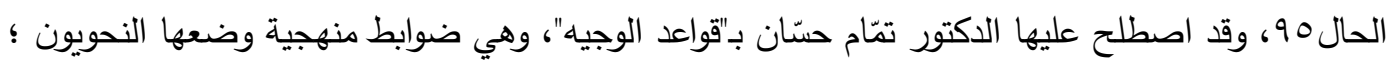

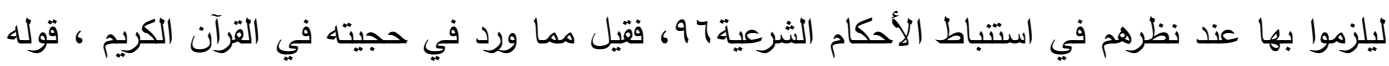

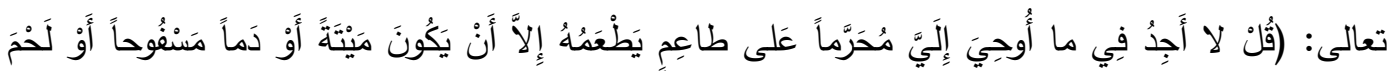

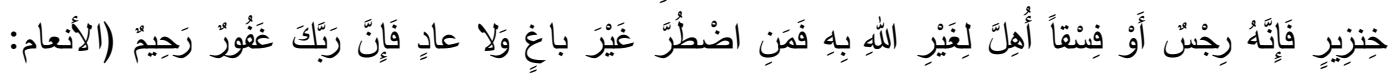

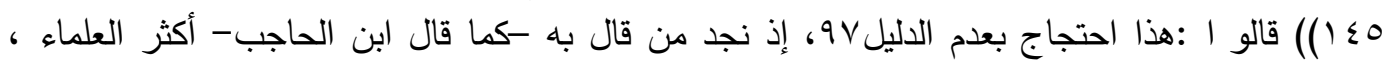

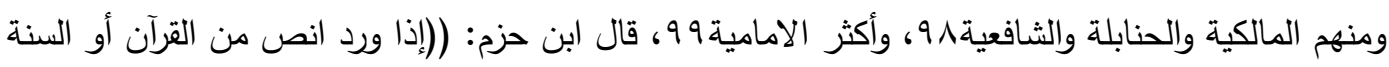

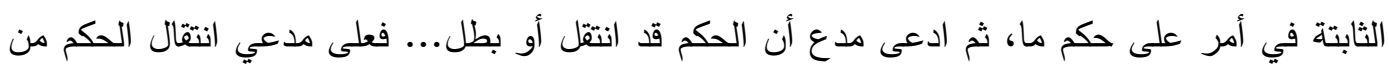

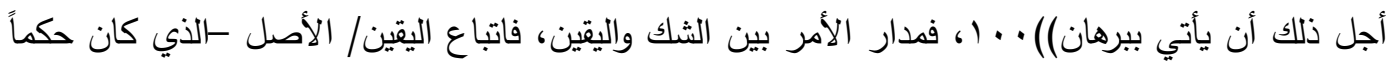

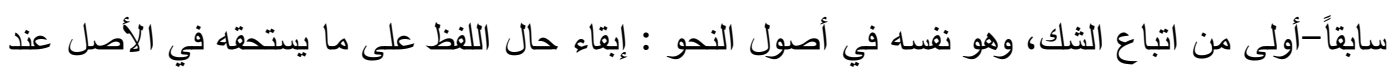

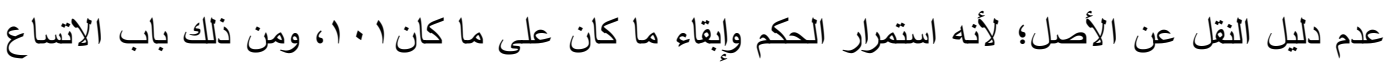

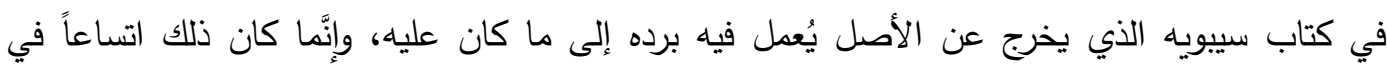




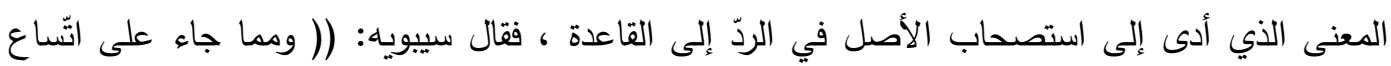

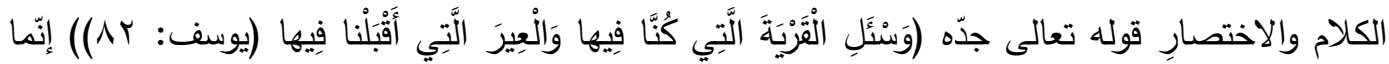

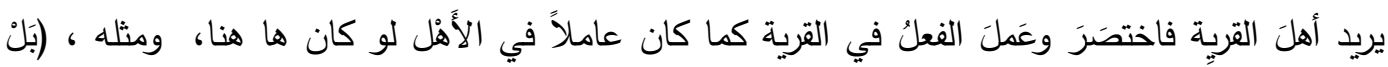

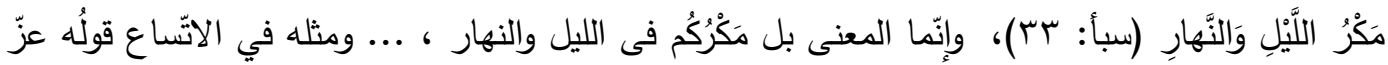

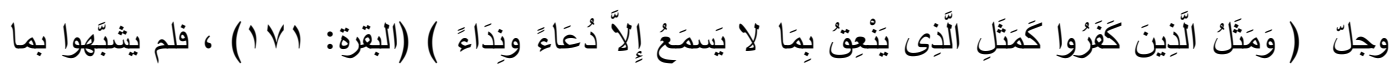

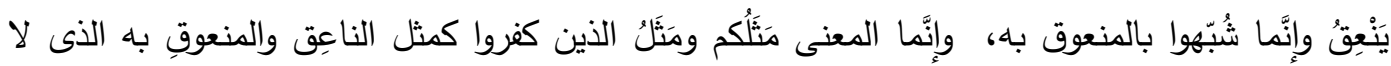

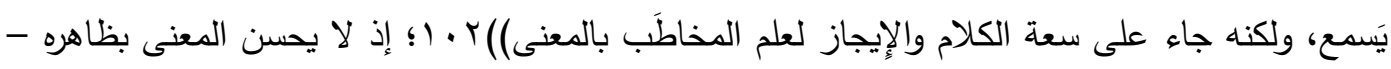

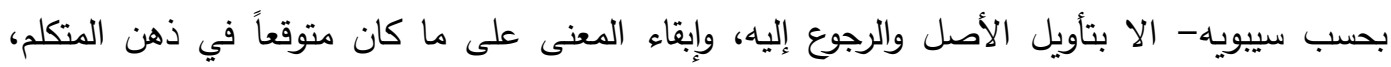

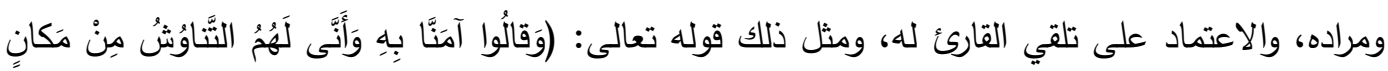

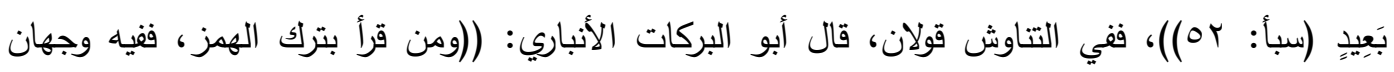

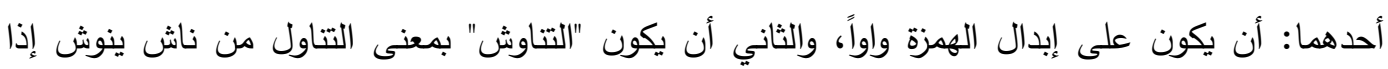

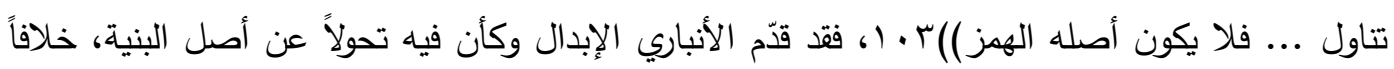

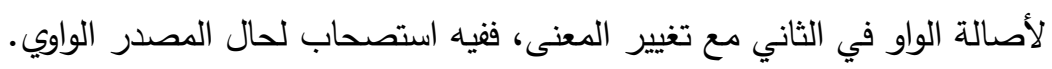

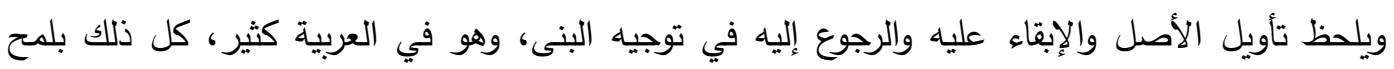

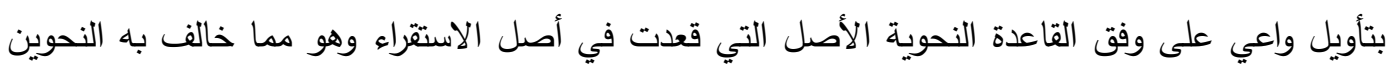

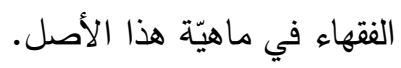
الأحكام

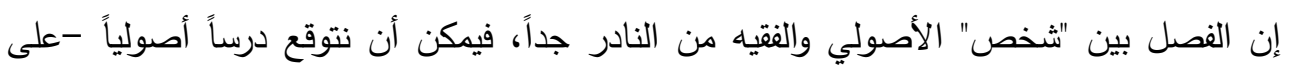

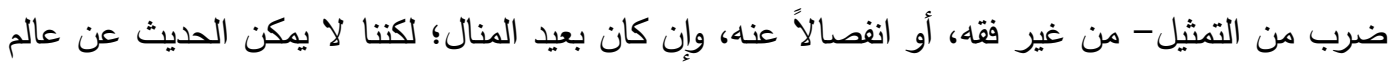

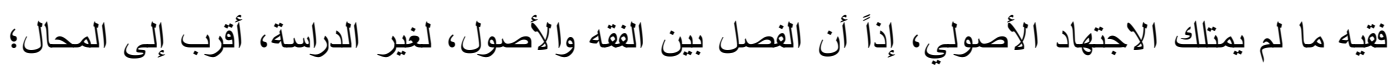

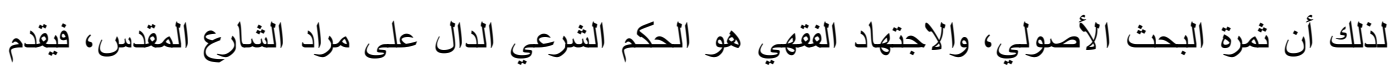

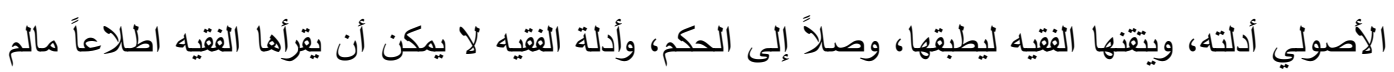

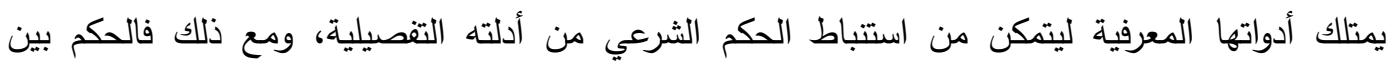

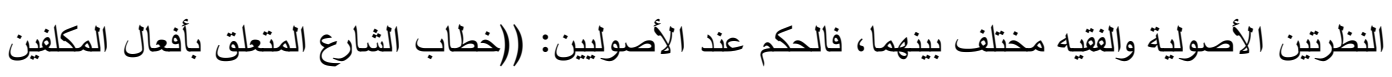

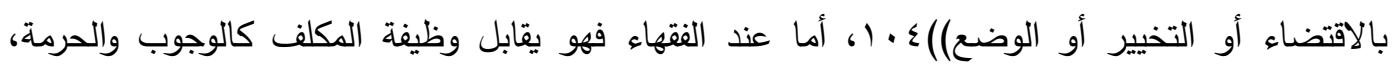
وغرهما حكماً شرعياً، بمعنى أن ((الحكم بطهارة من تيقن الطهارة وشك في الحدث، فلا يسمى حكماً شرعياً 
بمقتضى اصطلاح الفقهاء، ويسمونه وظيفة عملية ، ريثما يقوم الدليل على بيان الحكم الثرعي لهذه

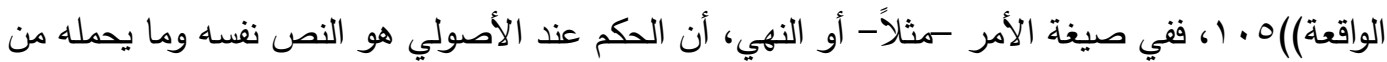

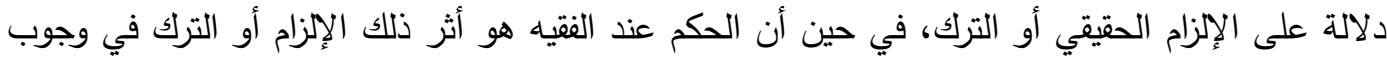

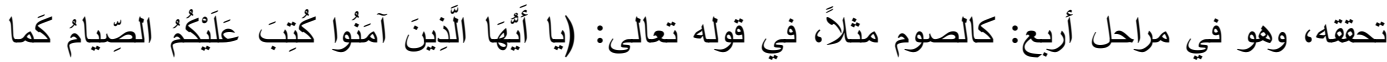

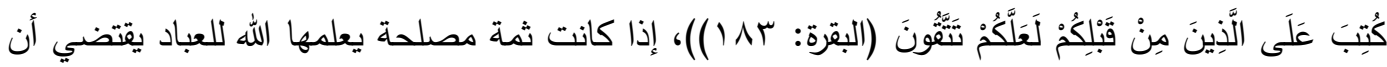

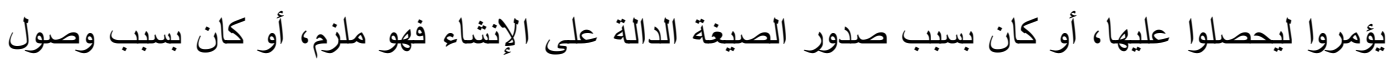

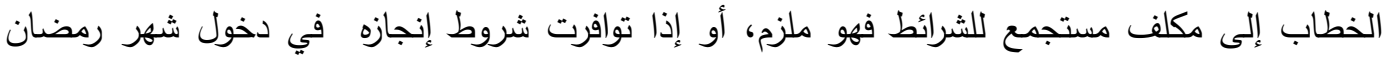

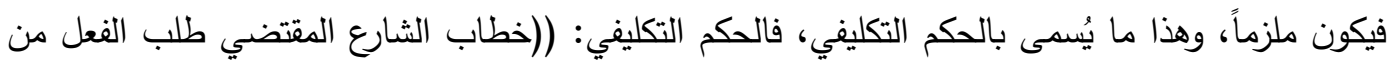

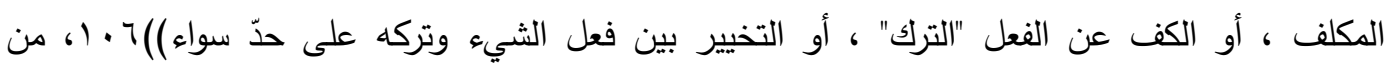

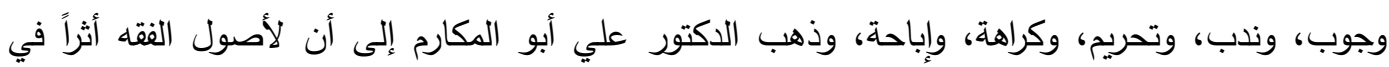

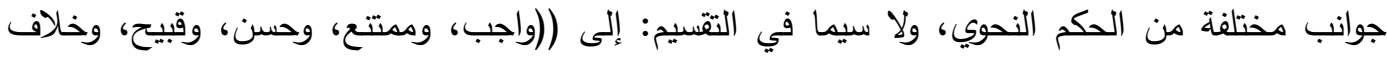

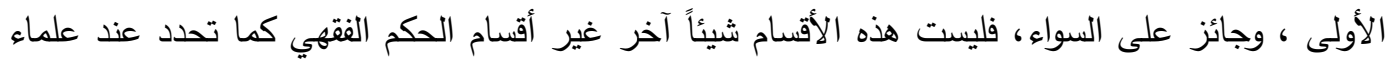

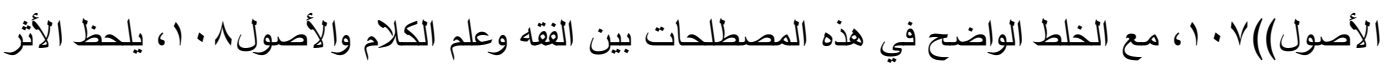

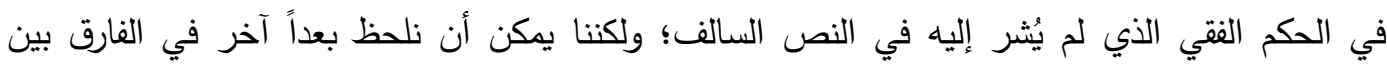

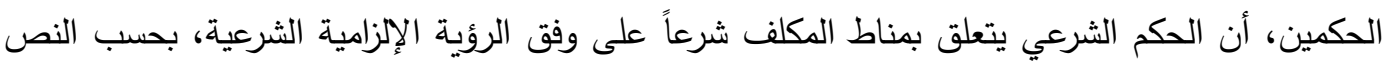

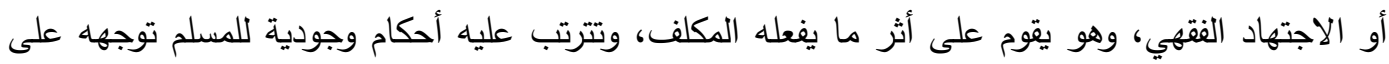

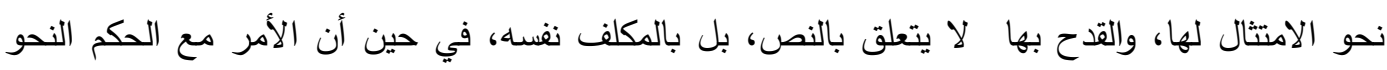

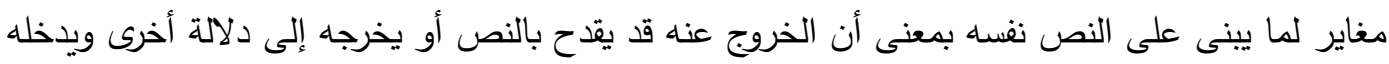

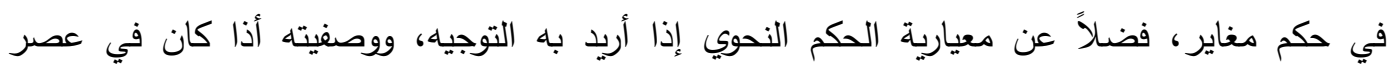

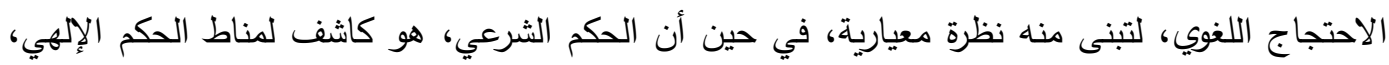

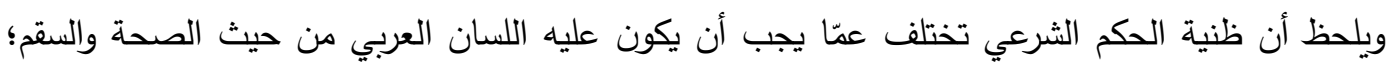
لأن هدف الفقيه التوصل إلى قصدية المشرع، في حين أن الهدف من الدراسة النئ النحوية تقويم اللسان،

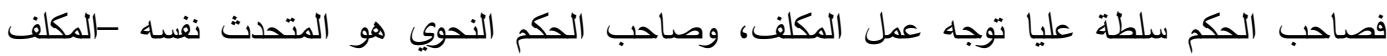

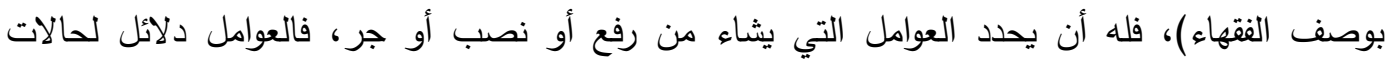

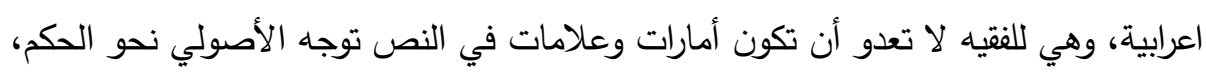

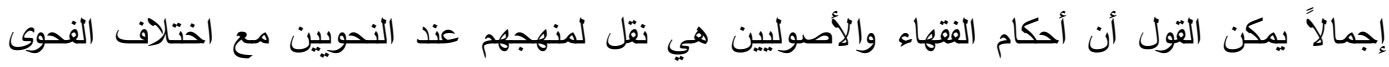
والمفهوم لكلَ منهما، فالنحوي كوالأصل فيه أنه لم يبتعد عن الفقه والأصول في عصره- قد "تنقل" الأككام 


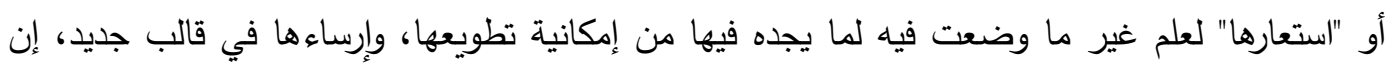

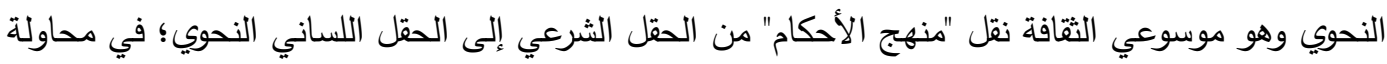

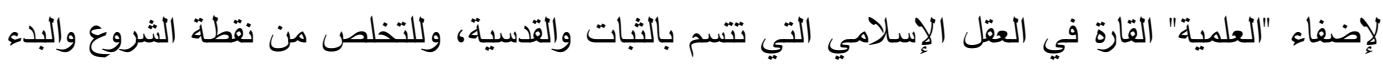
بتأسيس بناء أخر .

ونحن نتحدث عن "نقل" منهج الأحكام وقبله "نقل" منهج الاستنباط، لم يكن النقل قصرياً، بمعنى:

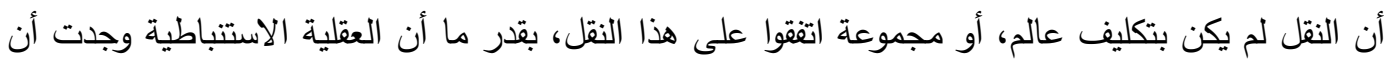

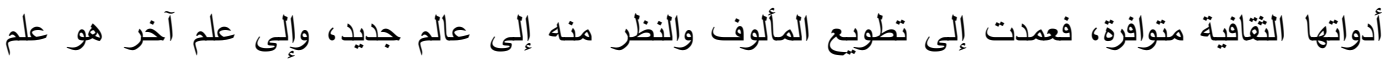

ذكر سييويه جملة من الأحكام النحوية في أوائل كتابة الذي سيفصل فيها أبواب الكتاب، ويقسمها،

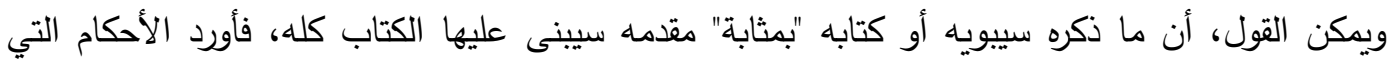

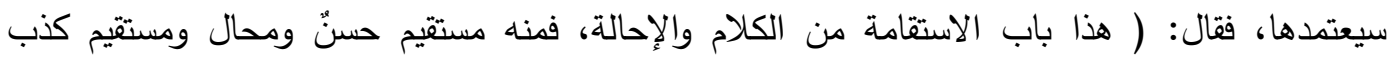

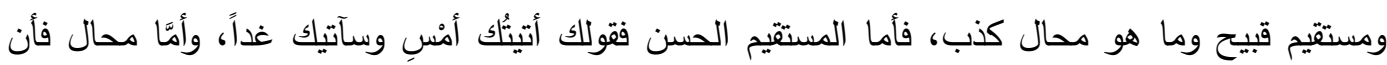

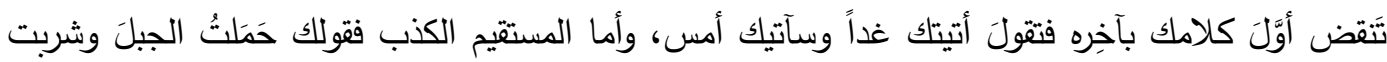

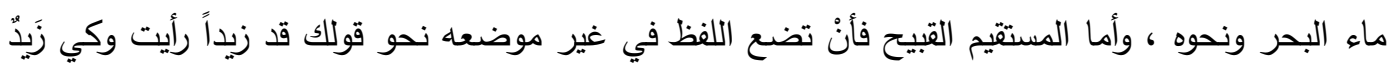

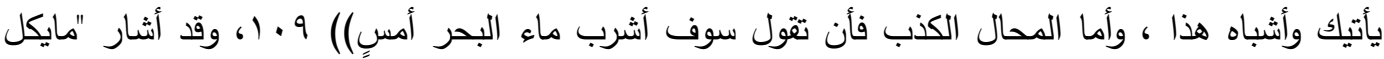

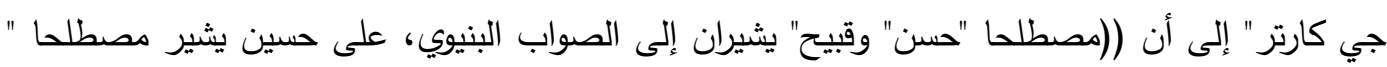

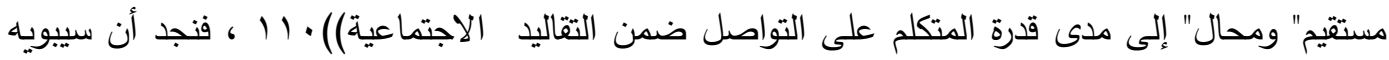

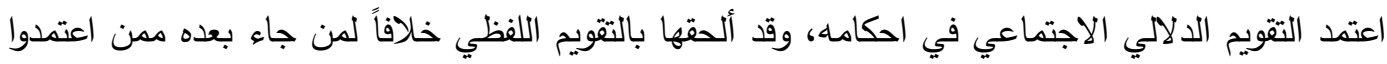

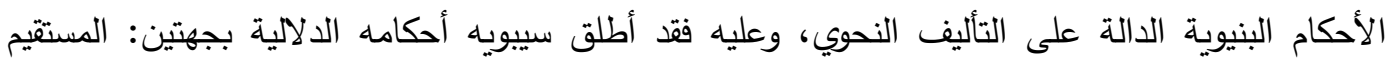

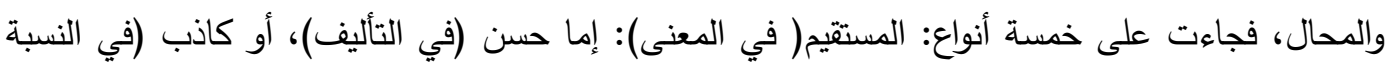

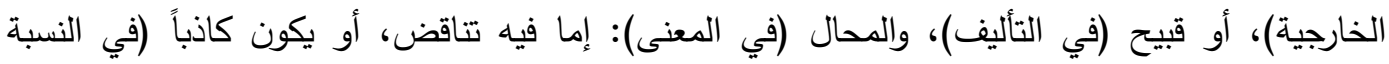

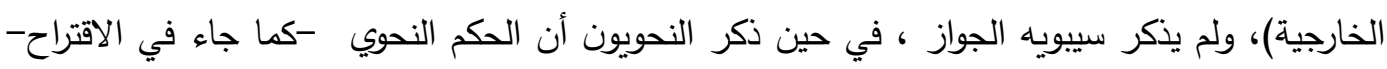

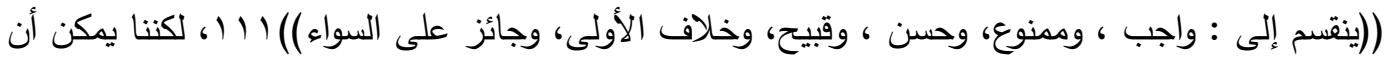

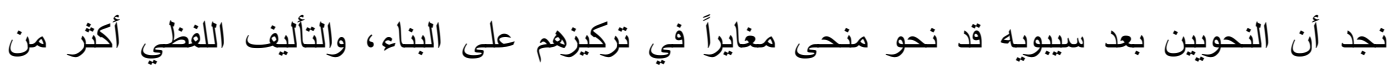
المنىى لذلك جاءت أحكامهم متساوقة مع أرادوا، ويمكن أن نستشعر العلاقة بين الأحكام في كلَّ مما يأتي: 
الواجب عند الفقهاء، ويقابله عند النحويين الوجوب، وعند سييويه المستقيم الحسن، فالوجوب: هو الإلزام

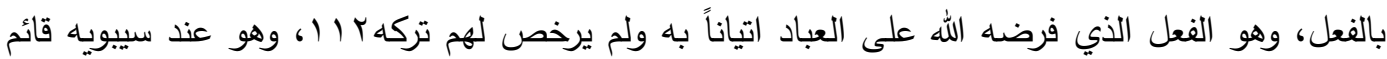

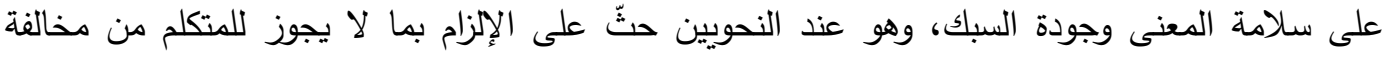

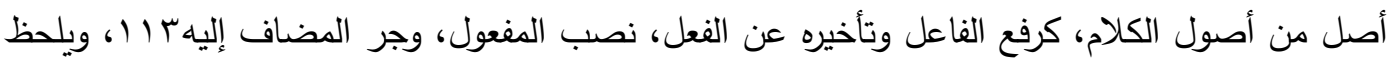

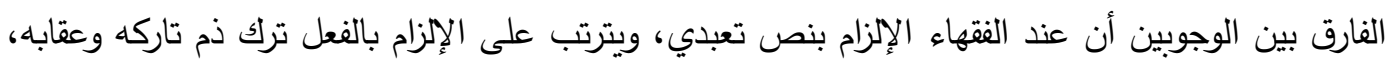

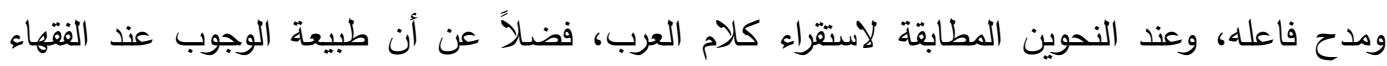

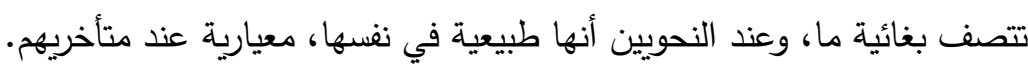

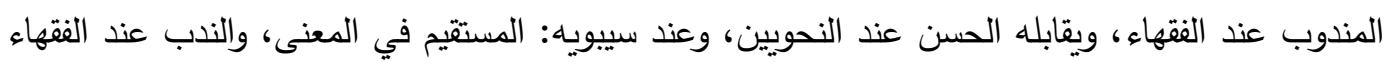

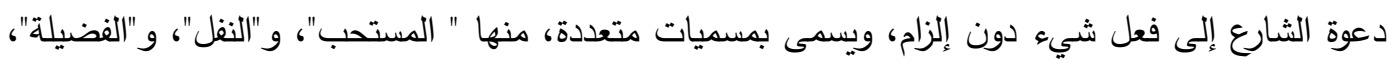

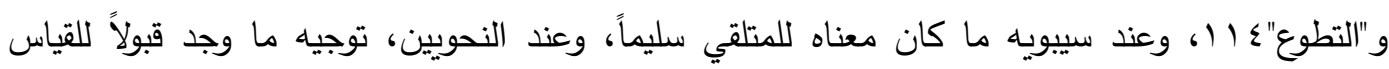

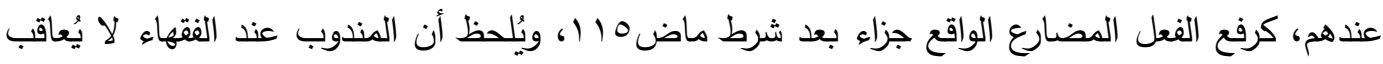

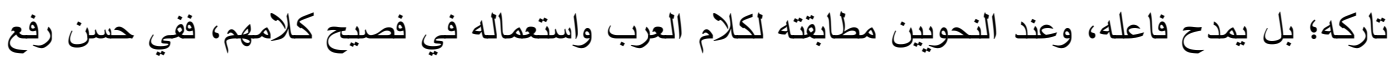

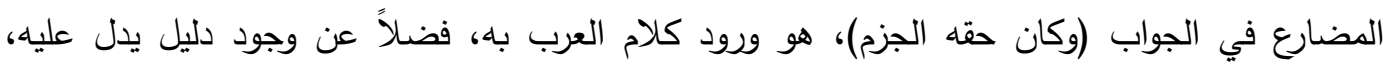

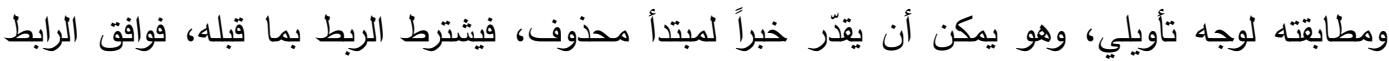

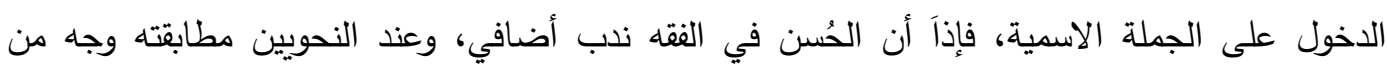
الوجوه.

الدحرم عند الفتهاء، ويقابله الممتنع عند النحويين، وعند سييويه المحال في التأليف النحوي، والمحال

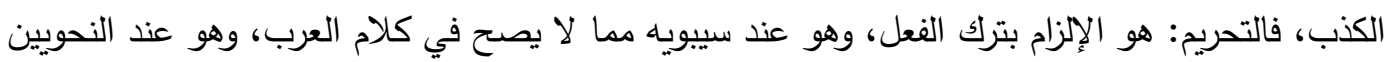

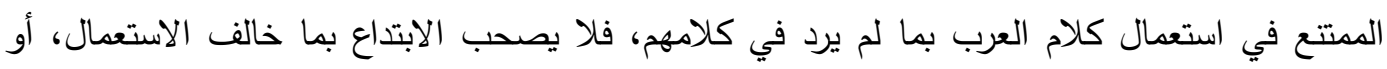

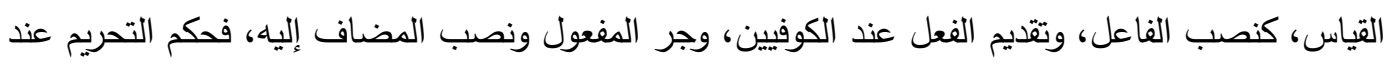

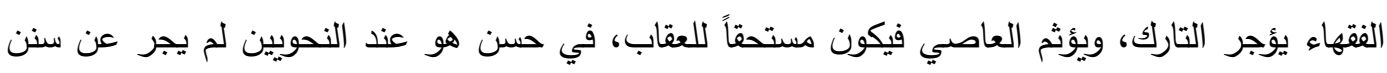

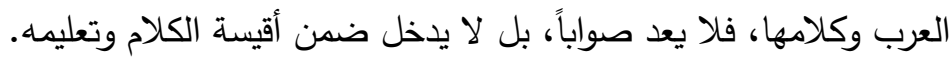
الكراهة عند الفقهاء، ويقابله القبيح في البناء عند النحويين، وعند سييوية: المستقيم القبيح، والكستقيم الكنب.

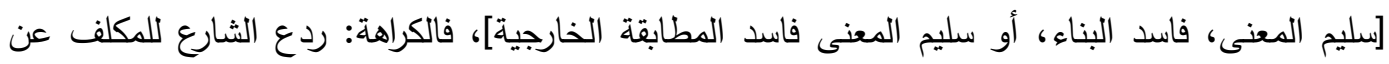

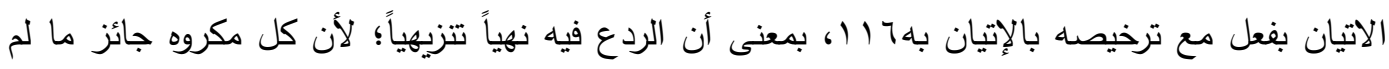

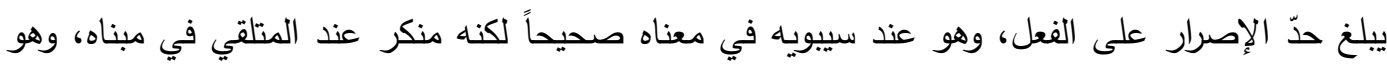

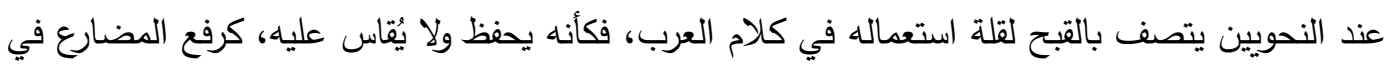


جواب شرط لمضارع| ||، ويلحظ عند الفقهاء أن ((تاركه يمدح ويثاب إذا تركه امتثالاً لنهي الله عنه، وإن فعله لا يستوجب الاثم ما لم ييلغ حدّ الإصرار على الفعل)/1 (1، وهو عند النحويين مما يحفظ ليكون

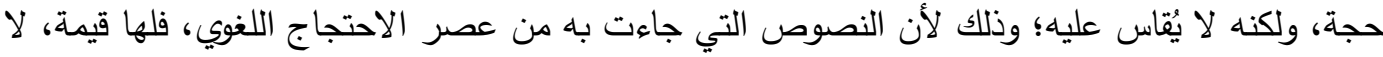

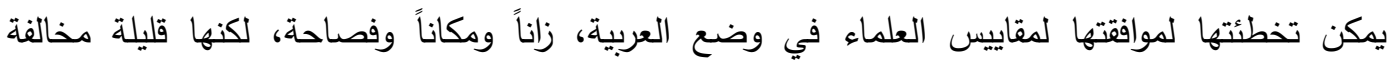
للمشهور، فيحكم بقبحها لموافتتها الاستعمال ومخالفتها القياس.

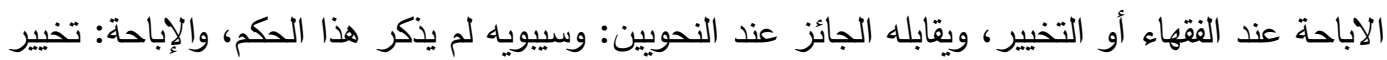

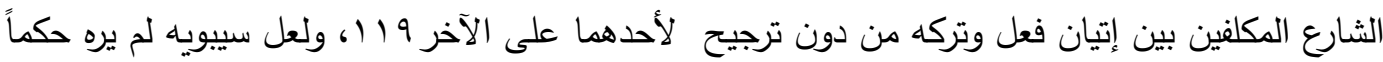

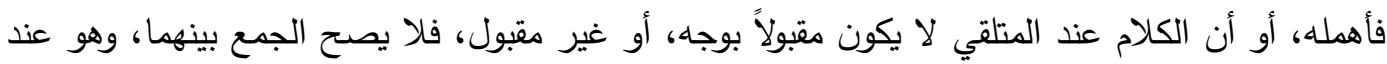

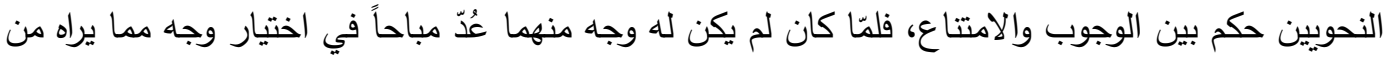

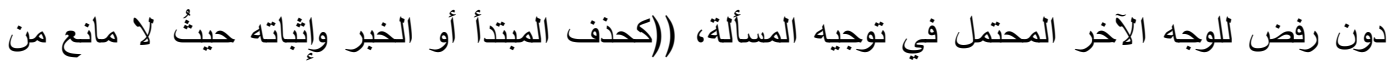

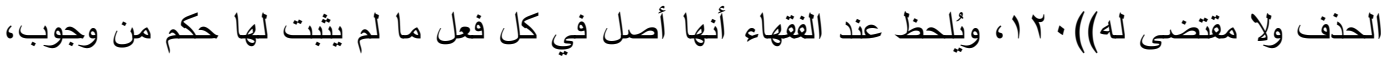

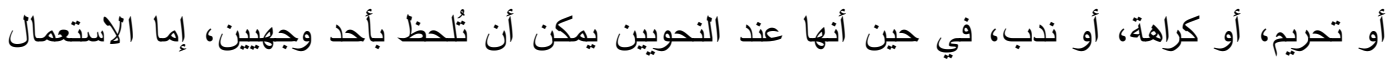

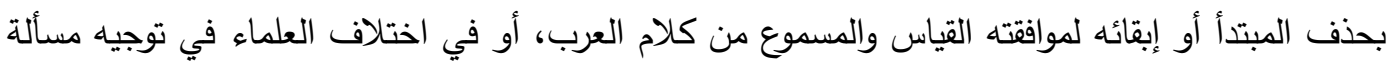

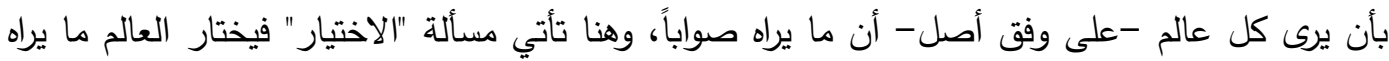

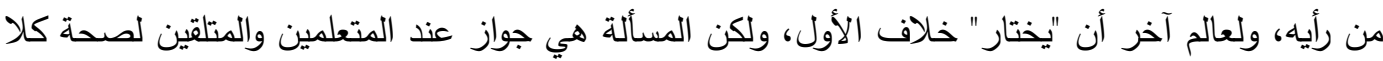

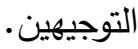

يشهد الخطاب النحوي العربي تأثراً واضحاً في المعرفة الفقهية للعالم الموسوعي الذي استعان بمصطلحات الفقه وأصوله بعد أن أضفى على الفحوى ما يميزه عن غيره من العلوم، والمدونة النحوية حافلة

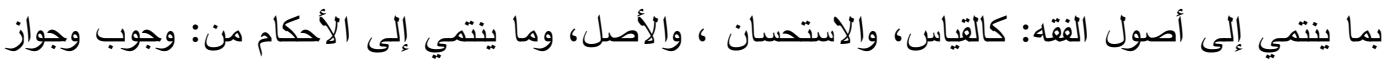

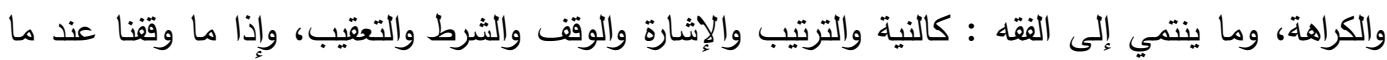

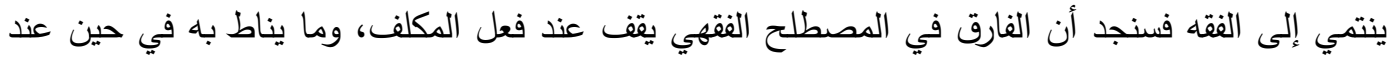

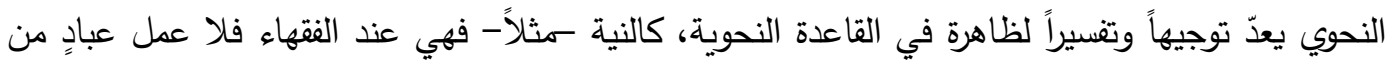

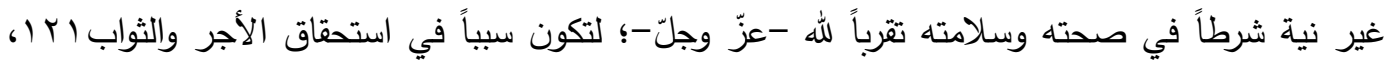

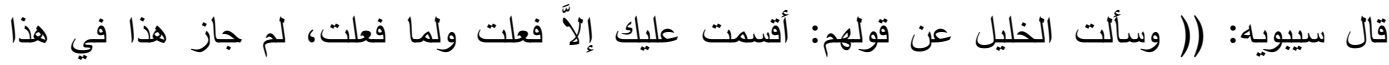
الموضح، وإنما أقسمت ها هنا كقولك: والَّه؟ فقال: وجه الكلام لتنعلنَّ، هاهنا ولكنهم إنما أجازوا هذا لأنهم 
شبهوه بنشدتك الله، إذ كان فيه معنى الطلب. وسألته عن قوله إذا جاءت مبتدأةً ليس قبلها ما يحلف به؟ فقال: إنما جاءت على نيَّة اليمين وإن لم يتكلَّم بالمحلوف به)) ب ب (، ومثل ذلك بيان حكم العطف ، وتقديم تفسير له في مثالنا : جاء زيد، وعمرو، أي: جاء زيد وجاء عمرو، على نية تكرار العامل فأخذ الثاني حكم

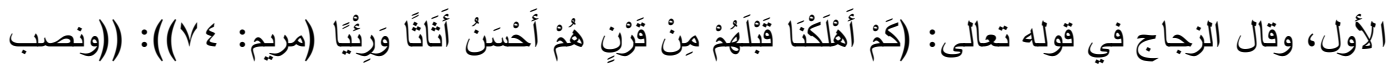

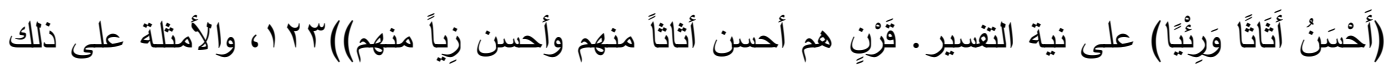
أكثر من أن تحصى تعدّ مصداقاً لذلك.

الخاتمة:

خلص البحث إلى أن الخطاب النحوي تأثر معرفياً بالخطاب الفقهي بشقيه: الأصول بأدلته الشرعية، والفقه بأحكامه الاستتباطية في مجالات متعددة: منهجاً، ومصطلحاً مع فارق تحويلي تتسجم مع طبيعة العلم، فلم يكن نسخاً تقريرياً، لينحو بهما منحى مغايراً ، ووقف البحث على أبعاد الدرس اللغوي بنيوياً في الصوت والصرف والتركيب؛ لأنه انتحاء لسمت العرب في كلامهم، وحدد البحث ذلك الأثر الاصطلاحي والمنهجي باتجاهات ثلاثة في الخطاب النحوي: الاتجاه الأول الاتجاه القاعدي المتمثل في القاعدة النحوية وخير من يمثله : كتاب سييويه لأنه يمثل مرحلة التأسيس وما تبعه من تقعيد نحوي اتخذ مسار المعيارية عند متأخري العلماء، والاتجاه الثاني، اتجاه التأصيل التتظيري الاستنباطي المتمثل بكتب أصول النحو العربي كالإغراب، ولمع الأدلة والاقتراح وغيرها، والاتجاه الثالث في الخطاب النحوي الاتجاه الاستعمالي القائم على قراءة النصوص على وفق الاتجاهيين السالفين وخير من يمثل هذا الاتجاه كتب معاني القرآن. 
الإحكام في أصول الأحكام: أبو الحسن سيد الدين علي بن أبي علي بن محم بن سالم الثعلبي الآمدي (المتوفى:

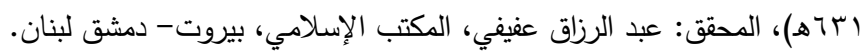
إرشاد الفحول إلي تحقيق الحق من علم الأصول: ححمد بن علي بن عحمد بن عبد الله الثوكاني اليمني (المتوفى: •

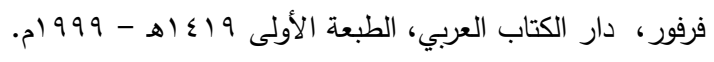
استصحاب الحال بين أصول الفقه وأصول النحو: د. عاطف الأولى فضل محمد خليل، مجلة جامعة أم القرى لعلوم الشريعة

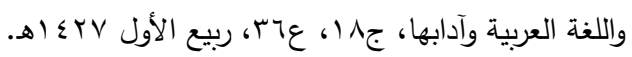

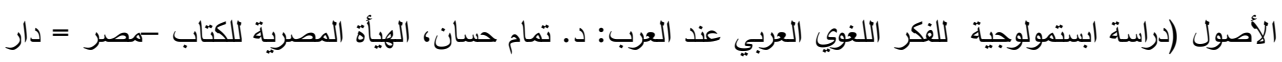

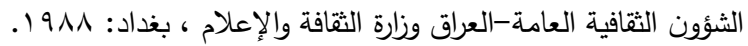

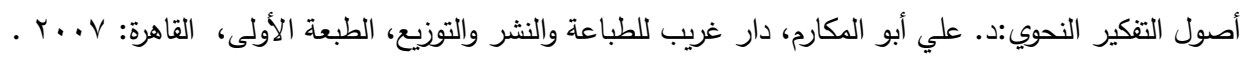

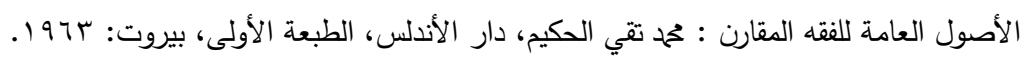

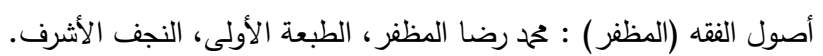
أصول النحو العربي في نظر النحاة ورأي ابن مضاء القرطبي وعلم اللغة الحديث:د. محمد عيد، عالم الكتب القاهرة: .01919 الأصول في النحو، أبو بكر محمد بن السري بن سهل النحوي المعروف بابن السراج (المتوفى: باسهـ)، المحقق: عبد الحسين الفتلي، مؤسسة الرسالة، لبنان - بيروت.

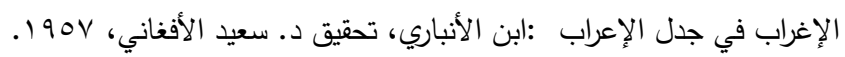

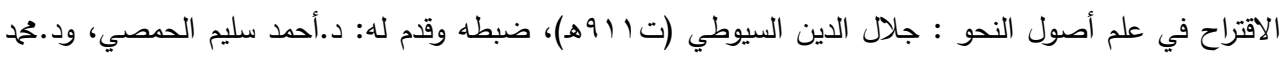

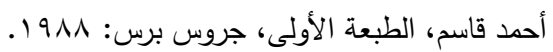

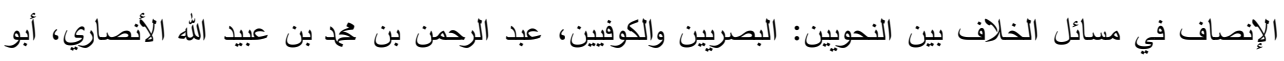

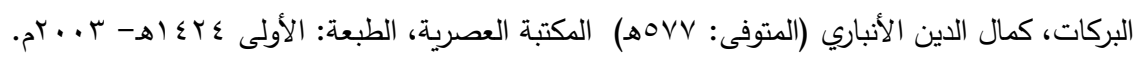

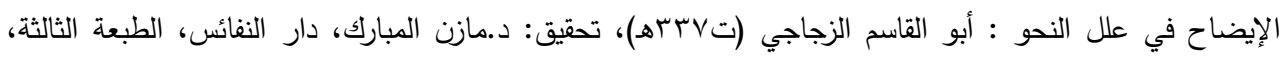

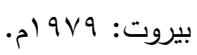

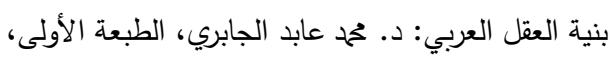

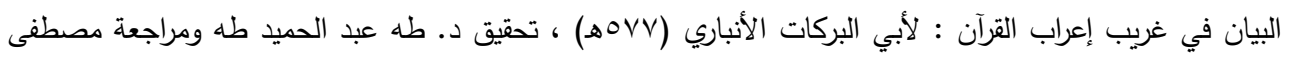

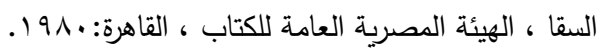
تاج العروس من جواهر القاموس، محمّد بن محمّد بن عبد الرزّاق الحسيني، أبو الفيض، الملقّب بمرتضى، الزَّبيدي

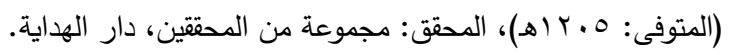

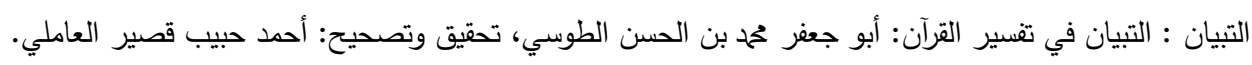

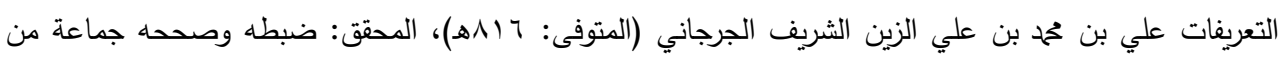

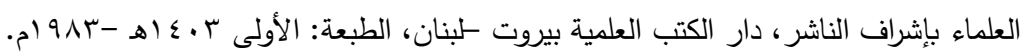




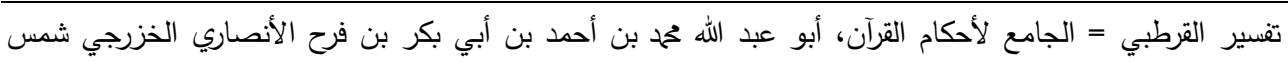

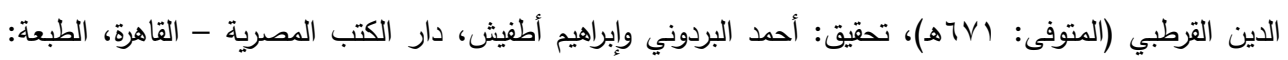

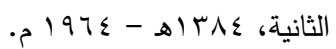

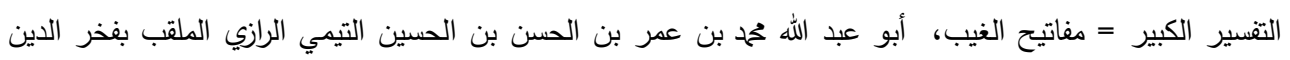

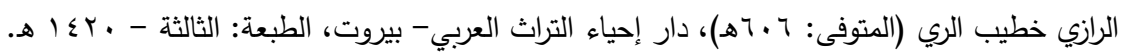

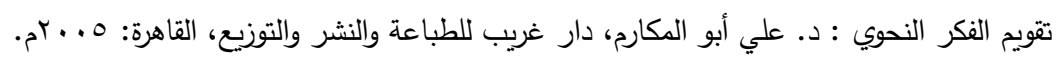

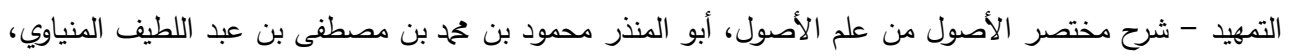

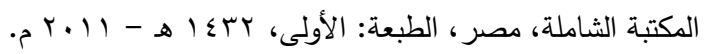
جمهرة الأمثال: أبو هلال الحسن بن عبد الله بن سهل بن سعيد بن يحيى بن مهران العسكري (المتوفى: نحو 90 بهـ)، دار الفكر - بيروت. - مان. خزانة الأدب وغاية الأرب، ابن حجة الحموي، تقي الدين أبو بكر بن علي بن عبد الله الحموي الأزراري (المتوفى:

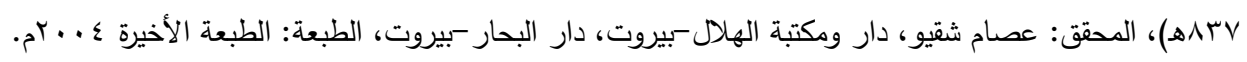

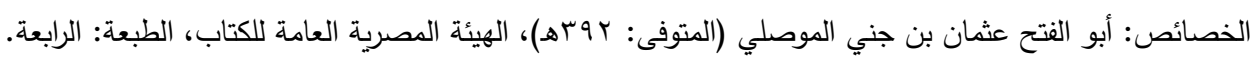

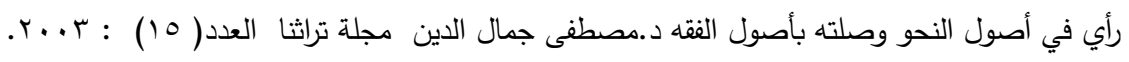

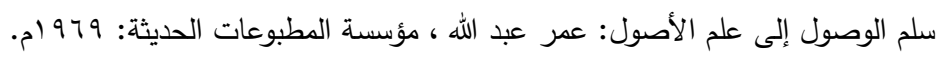

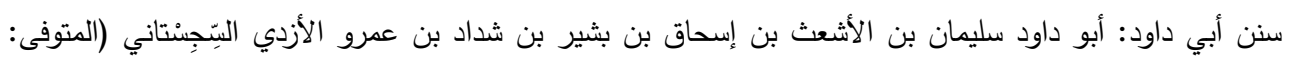

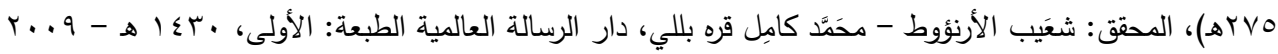

شرح ابن عقيل على ألفية ابن مالك: ابن عقيل ، عبد الله بن عبد الرحمن العقيلي الهمداني المصري (المتوفى :

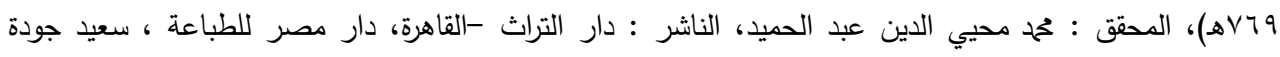

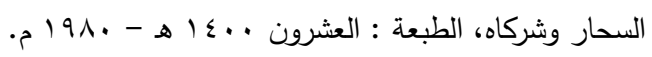

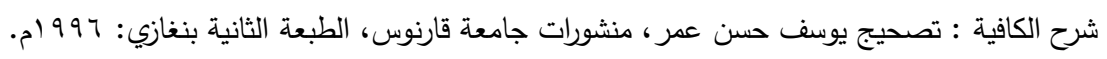

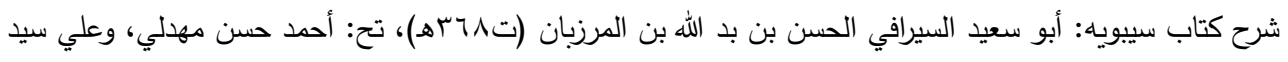

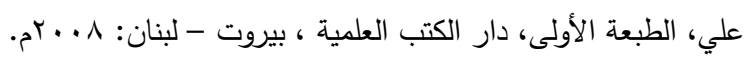

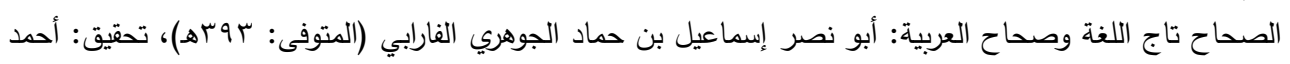

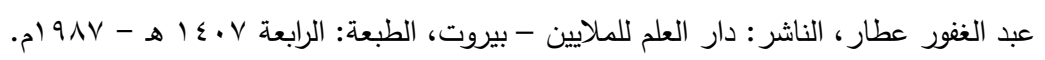

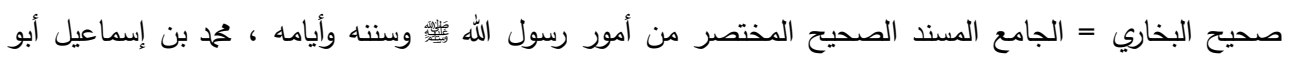
عبدالله البخاري الجعفي، المحقق: محمد زهير بن ناصر الناصر، دار طوق النجائ النجاة (مصورة عن السلطانية بإضافة ترقيم

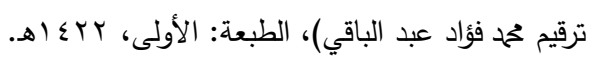

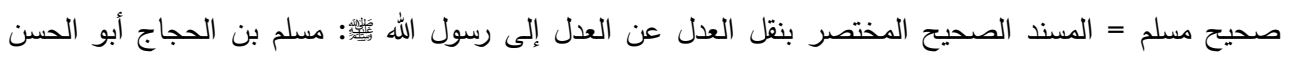
القشيري النيسابوري (المتوفى: (آrاهـ)، المحقق: محمد فؤاد عبد الباقي، دار إحياء التراث العربي - بيروت.

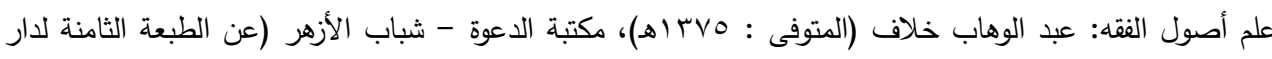
القلم)، الطبعة : عن الطبعة الثامنة لدار القلم. 
• العين [كتاب]، أبو عبد الرحمن الخليل بن أحمد بن عمرو بن تميم الفراهيدي البصري (المتوفى: • Vاهـ)، د مهدي

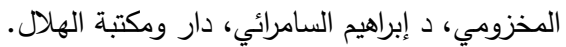

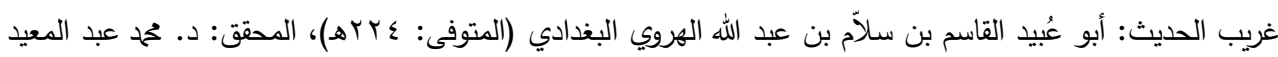

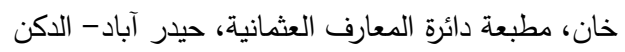

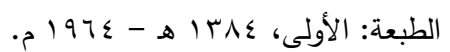

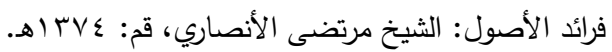

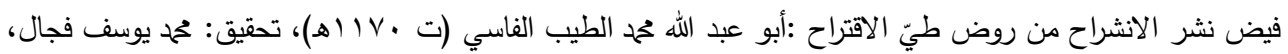

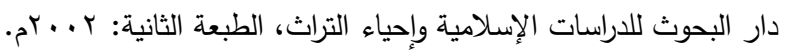

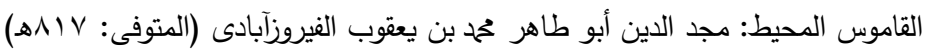

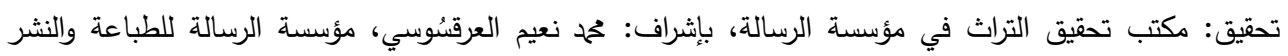

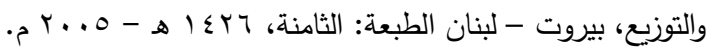

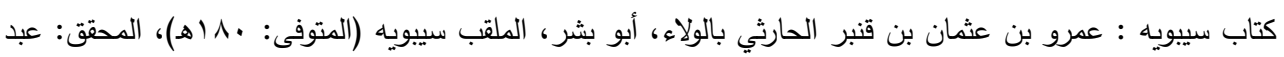

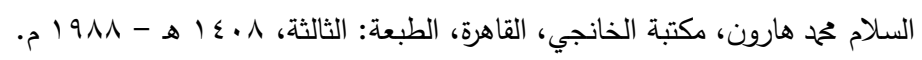
كثاف اصطلاح الفنون والعلوم : محمد بن علي ابن القاضي محمد حامد بن محمّد صابر الفاروقي الحنفي التهانوي

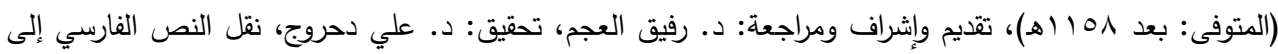

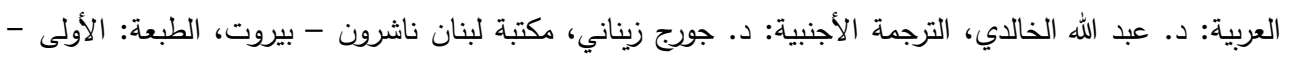
.01997 لسان العرب: ححم بن مكرم بن على، أبو الفضل، جمال الدين ابن منظور الأنصاري الرويفعى الإفريقى (المتوفى:

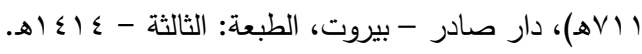
المستصفى: أبو حامد محمد بن محم الغزالي الطوسي (المتوفى: 0 ـ0هـ)، تحقيق: محمد عبد السلام عبد الثافي، الناشر:

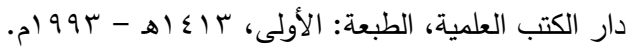

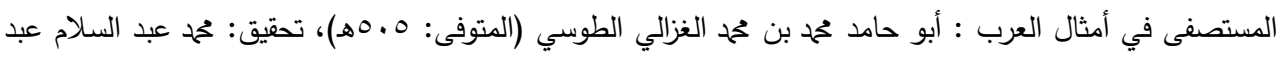

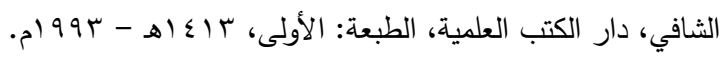

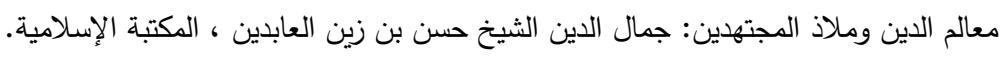

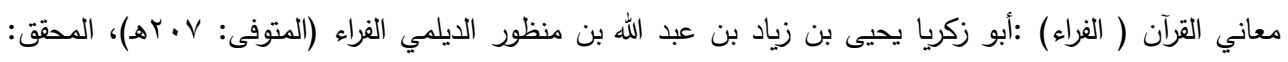

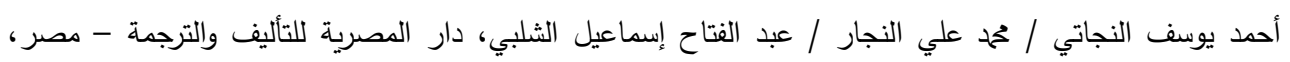

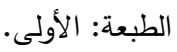

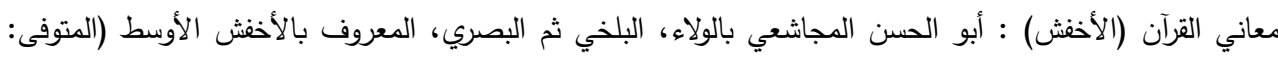

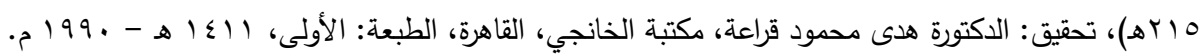

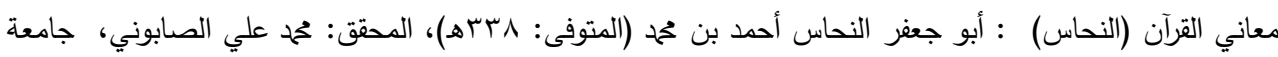

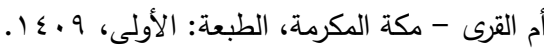

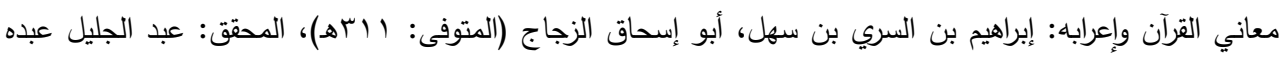

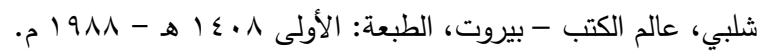


المعتمد في أصول الفقه: مححد بن علي الطيب أبو الحسين البَّْري المعتزلي (المتوفى: بس؟هـ)، المحقق: خليل الميس،

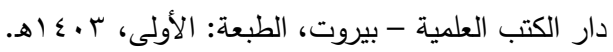
مفتاح الوصول إلى علم الأصول : د. أحمد كاظم البهادلي، الطبعة الأولى، شركة حسام للطباعة المحدودة، بغداد: .1990 مقاييس اللغة : أحمد بن فارس بن زكرياء القزويني الرازي، أبو الحسين (المتوفى: 90سه)، المحقق: عبد السلام محم

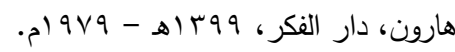

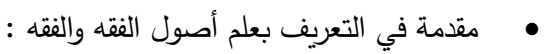
المقرب : علي بن مؤمن المعروف بابن عصفور: (7979هـ)، تحقيق: د. أحمد عبد الستار الجواري، ود. عبد الله

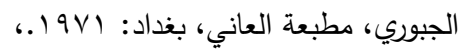
الموافقات : إبراهيم بن موسى بن محمد اللخمي الغرناطي الثهير بالثاطبي (المتوفى: ـVوهـ)، المحقق: أبو عبيدة

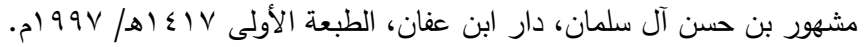

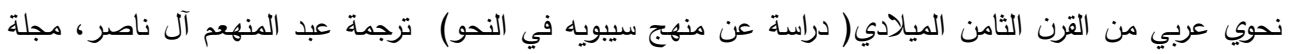

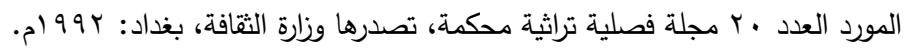
نزهة الألباء في طبقات الأدباء: عبد الرحمن بن حمح بن عبيد الله الأنصاري، أبو البركات، كمال الدين الأنباري (المتوفى: النشر في القراءات العشر : شمس الدين أبو الخير ابن الجزري، محمد بن محمد بن يوسف (المتوفى : بrی هـ)، المحقق :

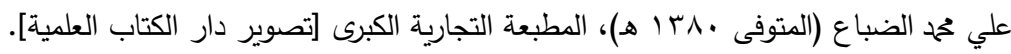

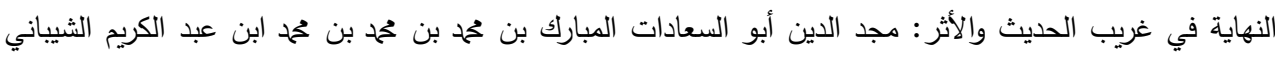
الجزري ابن الأثير (المتوفى: 7.7هـ)، تحقيق: طاهر أحمد الزاوى - محمود محمد الطناحي ، المكتبة العلمية -

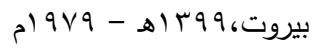
الوافي بالوفيات: صلاح الدين خليل بن أيبك بن عبد الله الصفدي (المتوفى: ـالهـه)، المحقق: أحمد الأرناؤوط وتركي

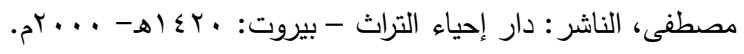

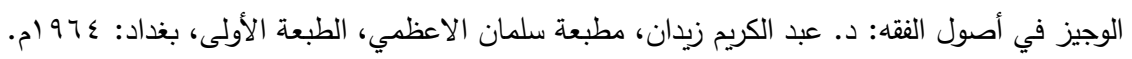


ا أريد به : الأثر الأصولي بأدلته الثرعية، والفقهي بأحكامه الاستباطية.

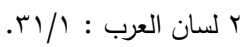

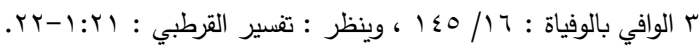

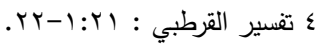

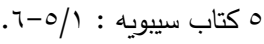

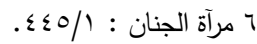

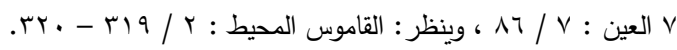

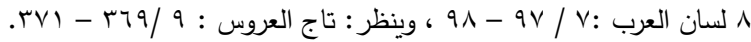

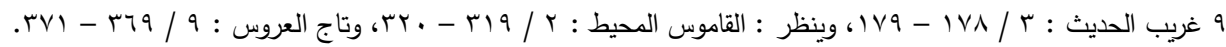

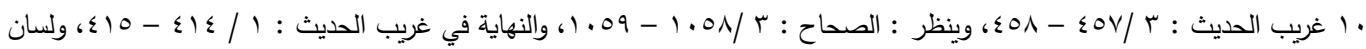

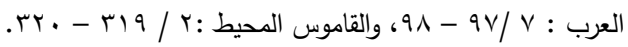

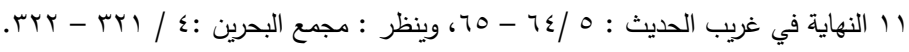
T T النهاية في غريب الحديث :

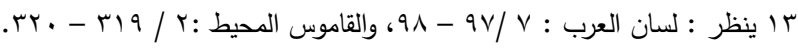

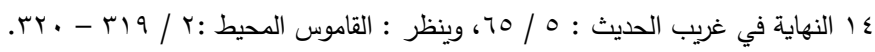

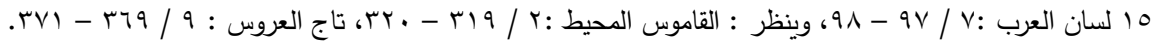

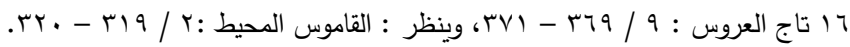
IV

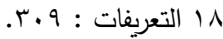

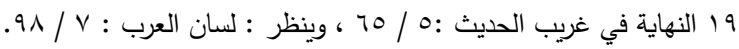

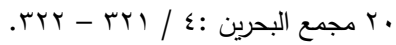

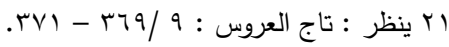

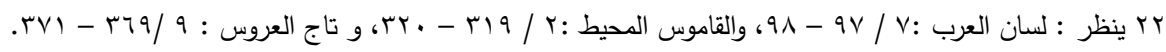

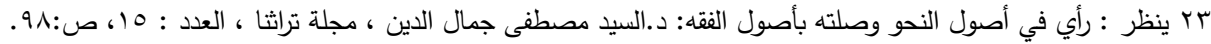

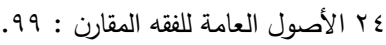

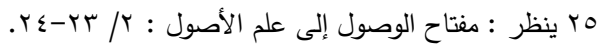

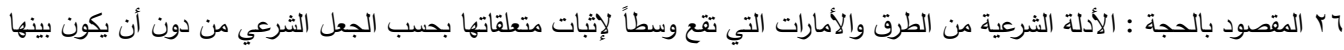

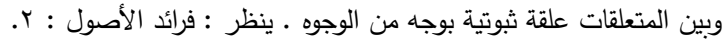

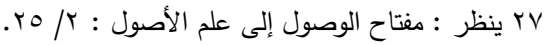

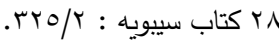

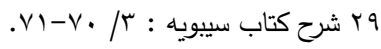

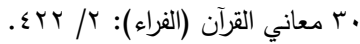

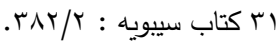

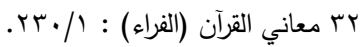




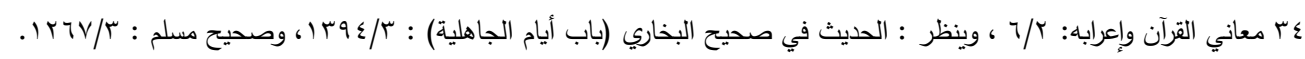

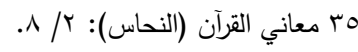
דr التفير الكبير : :

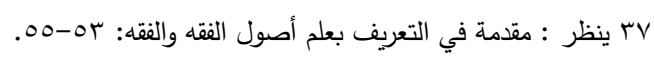

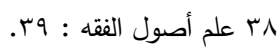

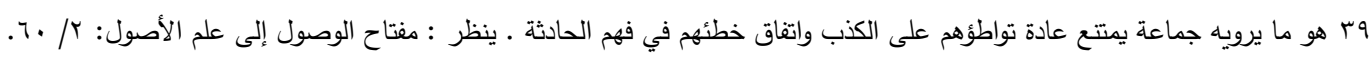

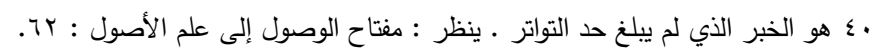

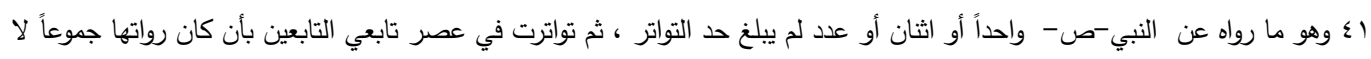

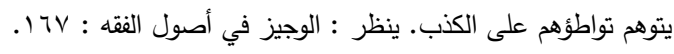

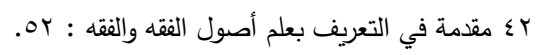

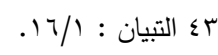

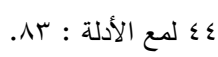
0 ك نفسه : 10.

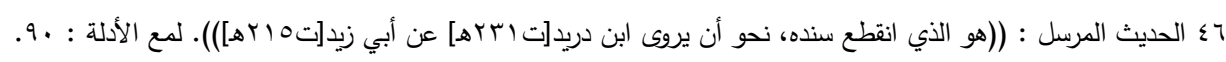

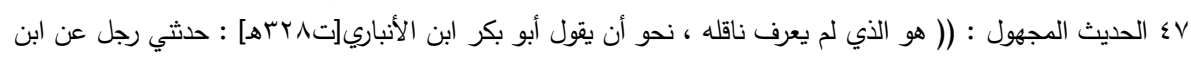

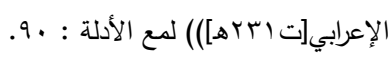

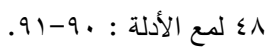

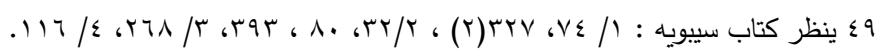

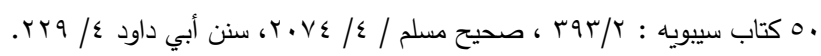

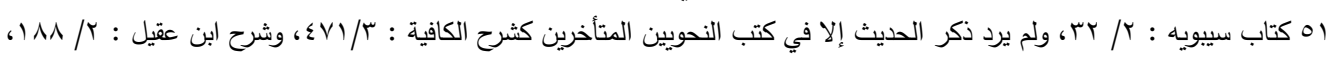

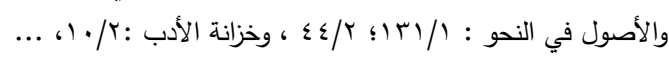
ror or or o معاني القرآن (النحاس): ك مه معاني القرآن (الأخفش): / / / بسان : (مقدمة المحققة). ع أصول الفقه (المظفر):

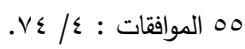

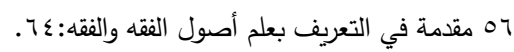

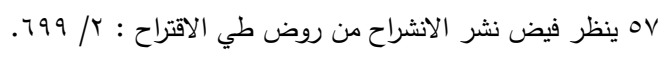

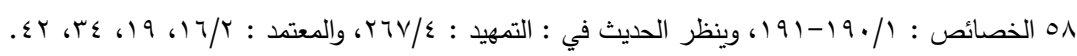

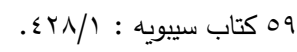

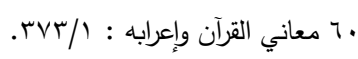
آ آ معاني القرآن (الفراء):

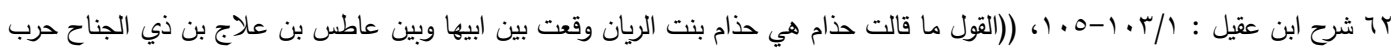

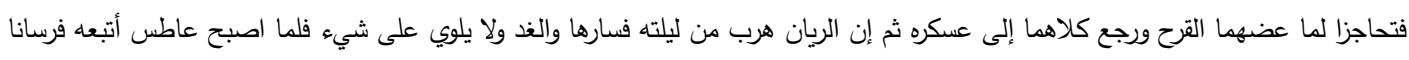

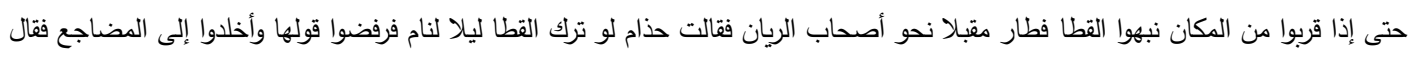
دميس بن ظالم الأعصري ( الوافر )

$$
\text { فإن القول ما قالت حذام }
$$
إذا قالت حذام فصدقوها 
فارتحلوا حتى لاذوا بواد قريب منهم فوجدوهم قد امتتعوا فرجعوا وقيل قائله لجيم بن صعب وحذام امرأته وهي قد خوفته بيات العدو فكذبها ثم بيتوها

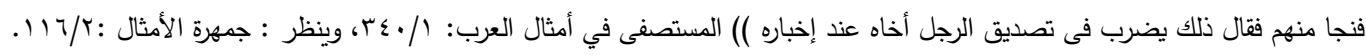

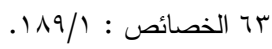
؛ 1 الخصائص : 19.

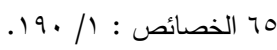

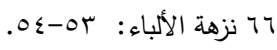

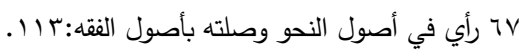

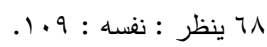

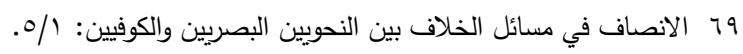

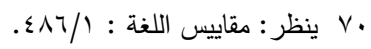

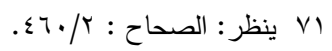

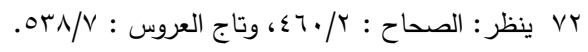

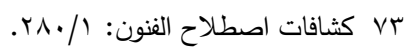

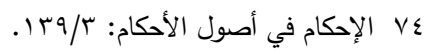
To

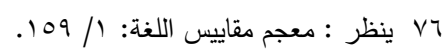
VV بنظر : معجم أصول الفقه : VV VV VA Na

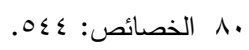

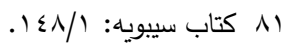

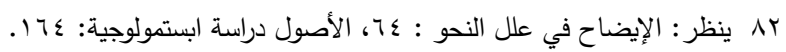

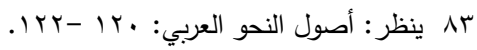

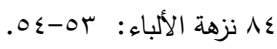

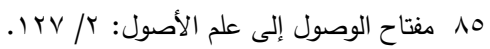

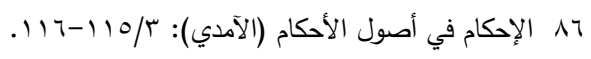

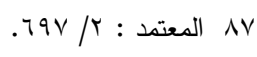

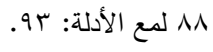

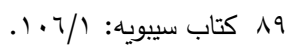

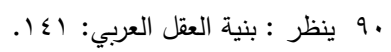

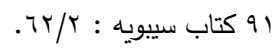

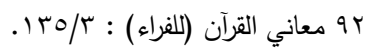

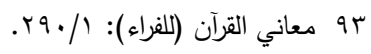

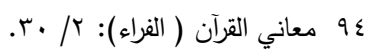

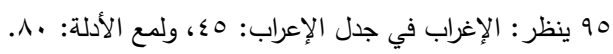

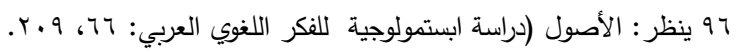




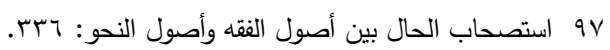

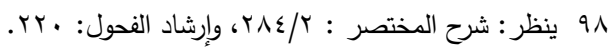

$$
\begin{aligned}
& 99
\end{aligned}
$$

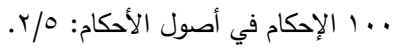

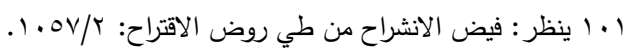

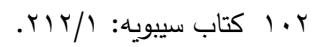

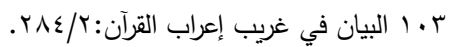

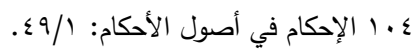

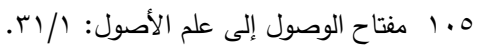

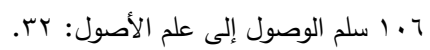

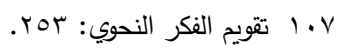

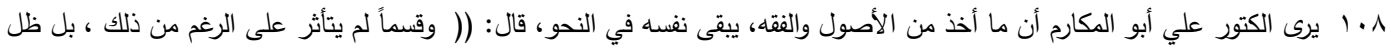

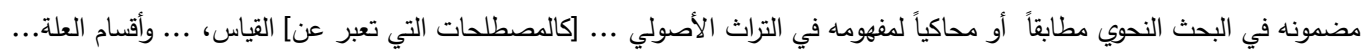

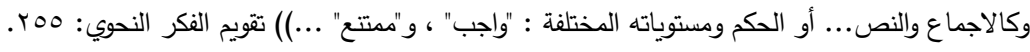

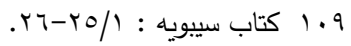

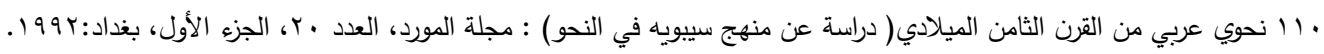
r11 111111

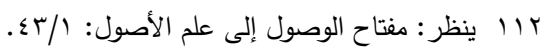

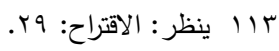

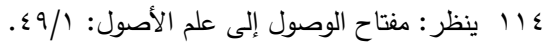

$$
\begin{aligned}
& 110 \\
& 117 \text { ينظر : مفتاح الوصول إلى علم الأصول: } 110 \\
& \text { ال } 11 \mathrm{~V}
\end{aligned}
$$

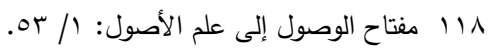

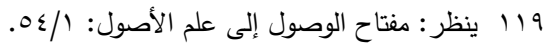

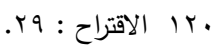

$$
\begin{aligned}
& \text { Ir } \\
& \text { r Tr } \\
& \text { rr }
\end{aligned}
$$

